\title{
Modele rozumowania dogmatycznego w prawie karnym
}

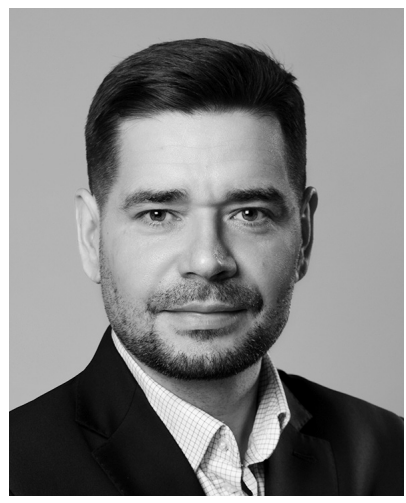

\section{Michat Królikowski}

Doktor habilitowany nauk prawnych, profesor Uniwersytetu Warszawskiego, adwokat, sędzia Sądu Arbitrażowego przy Prokuratorii Generalnej RP, w latach 2009-2015 członek Komisji Kodyfikacyjnej Prawa Karnego, w latach 2011-2014 podsekretarz stanu w Ministerstwie Sprawiedliwości, wcześniej dyrektor Biura Analiz Sejmowych.

$\triangle$ michal.krolikowski@uw.edu.pl https://orcid.org/oooo-0002-5775-4415

\section{Methods of Criminal Interpretations}

\begin{abstract}
There are few methods used by criminal lawyers determining how they approach to criminal provisions and final outcome in the procedural issue of being or not being held responsible for one's conduct. It might be illustrated that the main characteristic is something close to osmolarity of deeds that are close but not directly in the scope of criminal provision. In Poland it is determined by the culture of reasoning founded in the dark times of communism and afterwards simply retranslated to new democratic concepts. The author asks a question how legal dogmatics in criminal law may be the vehicle of individual guarantee to be held not guilty. According to the author this is the beginning to question the system, not the final word.
\end{abstract}

Słowa kluczowe: prawo karne, proces karny, teoria odpowiedzialności, przypisanie winy

Key words: criminal law, criminal procedure, methods of criminal interpretation, legal guarantees of accused, functions of criminal law

https://doi.org/10.32082/fp.v0i4(60).386

\section{Wprowadzenie}

Rekonstrukcja podstaw odpowiedzialności karnej oraz jej aplikacja w praktyce stosowania prawa jest, ujmując tę rzecz możliwie syntetycznie, istotą warsztatu dogmatycznego nad jakim koncentrują się przedstawiciele nauki prawa karnego, a w konsekwencji - do pewnego stopnia - również stosujący to prawo ${ }^{1}$. Dogmatyka karnistyczna to metoda naukowa, dzięki

1 J. Kochanowski, O zbędności teorii przyczynowości w prawie karnym, „Państwo i Prawo” 1967, nr 11, s. 780-790. której organy wymiaru sprawiedliwości na podstawie posiadanej wiedzy wywodzą z założeń wyjściowych (dogmatów) podstawy odpowiedzialności karnej za dane zachowanie i stosują je w rozpatrywanych przypadkach ${ }^{2}$. Jest to dyscyplina rekonstrukcyjna, albowiem jej celem jest odtworzenie zakresu kryminalizacji, rozumianej jako zespolenie zakazu i podstaw odpowiedzialności jednostki

\footnotetext{
2 P. Kardas, Teoretyczne podstawy odpowiedzialności karnej za przestępcze współdziałanie, Kraków 2001, s. $58 \mathrm{i} \mathrm{n.}$
} 
za jego naruszenie. Zarazem jest ona dyscypliną krytyczną opartą na metodzie weryfikacji wyniku procesu stanowienia i stosowania prawa. Zakłada wszak konieczność wypracowywania rozwiązań godzących ewentualne niezgodności lub precyzujących brak jednoznaczności w obowiązującej regulacji, weryfikację przepisów ustawowych w świetle konstytucyjnego systemu dóbr chronionych prawem i innych uwarunkowań ustrojowych, a także stosowanie mechanizmów korygujących, takich jak okoliczności legalizujące, rozstrzygnięcia kolizyjne czy wartościowanie słusznościowe.

O ile celem dogmatyki prawa karnego jest określona interpretacja aksjomatyczno-logiczna, o tyle już jej przeprowadzenie zależy od przyjęcia określonego warsztatu i aparatu pojęciowego. W tym właśnie momencie myślowe ścieżki karnistów zaczynają się rozchodzić. Jedni akcentują konieczność pierwszeństwa analityki znamion i akceptują płynące $\mathrm{z}$ niej domniemania przestępności analizowanego zachowania. Inni domagają się włączania do interpretacji karnistycznej zagadnień z zakresu teorii i filozofii prawa ${ }^{3}$. W końcu są i tacy, którzy opowiadają się za dominacją ogólnych struktur normatywnych, stanowiących wynik recepcji określonych koncepcji teoretycznoprawnych na grunt dogmatyki prawa karnego ${ }^{4}$. W tym pochodzie klasyczna analiza dogmatyczna przekształca się w coraz bardziej ukierunkowaną teoretycznie analizę podstaw odpowiedzialności karnej aplikowanej do konkretnych przypadków. Oczywiście, odróżnienie i wartościowanie modeli analizy dogmatycznej w prawie karnym jest przede wszystkim wyrazem konwencji, choć do samej tylko konwencji się nie sprowadza.

3 A. Zoll, O normie prawnej z punktu widzenia prawa karnego, „Krakowskie Studia Prawnicze” 1991, nr 23; W. Wróbel, Struktura normatywna przepisu prawa karnego, „Ruch Prawniczy, Ekonomiczny i Socjologiczny” 2003, nr 3, s. 102 i n.; tenże, Konstrukcja kontratypu jako sposób uadekwatniania treści normy sankcjonowanej i sankcjonujacej w procesie wykładni prawa karnego (w:) W poszukiwaniu dobra wspólnego. Ksiegga jubileuszowa Profesora Macieja Zielińskiego, red. A. Choduń, S. Czepita, Szczecin 2009.

4 Por. R. Dębski, Jeszcze o normie prawnokarnej (w:) Nauki penalne wobec szybkich przemian socjokulturowych. Ksiegga jubileuszowa Profesora Mariana Filara, t. 1, Toruń 2012, s. 118 i n.
Moim zamiarem jest opis kierunkowych różnic teoretycznych w metodzie analizy dogmatycznej w nauce prawa karnego, które mają istotny wpływ na to, jaką ma ona funkcjonalność, jaki potencjał dowodowy czy gwarancyjny, czy też jakim celom służy. Za zasadne uważam wyodrębnienie trzech podejść warsztatowych do pracy z materiałem prawnych w obrębie zagadnień związanych z odpowiedzialnością karną jednostki. Nie są one bynajmniej rozłączne, o wyróżnieniu decyduje przede wszystkim ukierunkowanie danej metody dogmatycznej i jej aplikacji do praktyki stosowania prawa karnego. Za pierwszy wiodący kierunek uważam metodę zbliżoną do klasycznej interpretacji karnistycznej, której przedstawiciele uważają za zasadne koncentrowanie się na odrębnej gałęziowo teleologii prawnokarnej oraz lokowaniu podstawowych problemów teoretycznych w obrębie zespołów znamion czynu zabronionego ${ }^{5}$. Drugim kierunkiem jest metoda przewagi znaczenia ogólnych struktur normatywnych w analizie prawnokarnej - wśród jej przedstawicieli dominuje pogląd, że kategoria normy prawnej jest jednym z kluczowych narzędzi analizy karnistycznej ${ }^{6}$. W końcu jako trzeci kierunek wskazać trzeba analizę odwołującą się do zewnętrznych względem prawa karnego kontekstów argumentacyjnych - metodę nakierowaną na osiąganie pożądanego aksjologicznie wyniku argumentacji prawnokarnej w świetle kryteriów materialnych, nie formalno-dogmatycznych ${ }^{7}$.

5 Z. Jędrzejewski, Bezprawność jako element przestępności czynu, Warszawa 2009; S. Żółtek, Znaczenie normatywne ustawowych znamion typu czynu zabronionego. Z zagadnień semantycznej strony zakazu karnego, Warszawa 2016; L. Gardocki, Pozaustawowe źródła znaczenia przepisu karnego (w:) W kręgu teorii i praktyki prawa karnego. Księga poświęcona pamięci profesora Andrzeja Waska, Lublin 2005. Zob. również P. Kardas, O relacjach między strukturą przestępstwa a dekodowanymi z przepisów prawa karnego strukturami normatywnymi, „Czasopismo Prawa Karnego i Nauk Penalnych” (dalej „CzPKiNP”) 2012, z. 4.

6 J. Majewski, O schemacie budowy norm prawa karnego w piśmiennictwie karnistycznym (w:) Źródła prawa karnego, red. T. Bojarski, „System Prawa Karnego”, t. 2, Warszawa 2011, s. 459

7 Przykładowo choć autorów wiele różni, to łączy ich poszukiwanie pozajęzykowe wartości rozstrzygających o prawidłowości modelu odpowiedzialności karnej: J. Kochanowski, 
W proponowanym porównaniu nie chodzi o kategorialną konkurencję konstrukcji narzędzi analizy materiału prawnego, ale o zestawienie sposobów ukształtowania warsztatu analitycznego, gdzie obrabia się zagadnienia z zakresu odpowiedzialności karnej. Interesuje mnie zatem konkurencyjność funkcjonalno-metodologiczna kierunków dogmatycznych odnoszona do efektywności ścigania w świetle postępowania dowodowego oraz zdolność spełnienia warunków gwarancyjnych względem jednostki przez praktykę stosowania prawa karnego. Jestem przekonany, że dorobek dogmatyczny powinien być poddawany praktycznym ności nie poniosła, a winny poniósł ją w pożądanych, bynajmniej nie arbitralnych ramach. Nie chodzi przy tym wyłącznie o to, że dogmatyka jako taka, tworząc pojęcia i kryteria argumentacyjne, stawia określone granice, umożliwia pewne i obliczalne stosowanie prawa karnego, pozbawione dowolności, ale także o to, że narzędzia i metody dogmatyczne, które ze względu na ich konkurencję teoretyczną mogłyby być stosunkowo dowolnie dobierane, powinny być wartościowane i poddane selekcji ze względu na ich przydatność i potencjał w postępowaniu dowodowym w perspektywie celu procesu karnego, a mianowicie uzyskania sprawiedliwego

\section{Wiarygodność dogmatyczna to wiodący nośnik} gwarancji praw jednostki w procesie stosowania prawa, siłą rzeczy zorientowanego na efektywność ścigania osób podejrzanych o popełnienie przestępstwa.

testom aplikacyjnym w celu poszukiwania sposobu osiągnięcia wiarygodności wyniku aplikacji zasad odpowiedzialności karnej w konkretnym przypadku. Wiarygodność ta jest w mojej ocenie wiodącym nośnikiem gwarancji praw jednostki w procesie stosowania prawa, siłą rzeczy zorientowanego na efektywność ścigania osób objętych podejrzeniem popełnienia przestępstwa. Staje się dowodem na to, że proces aplikacji zasad odpowiedzialności karnej w indywidualnym przypadku został wyważony między uproszczeniami wywodzonymi z potrzeby ukarania, niekiedy ujmowanej zresztą w bardzo zsubiektywizowany lub upolityczniony sposób, a pożądanymi wymogami materialnoprawnymi i dowodowymi w zakresie wykazania zasadności pociągnięcia do odpowiedzialności karnej sprawcy przestępstwa, tak by osoba niewinna tej odpowiedzial-

\footnotetext{
Subiektywne i obiektywne granice odpowiedzialności karnej, Warszawa 1982; K. Szczucki, Wykładnia prokonstytucyjna prawa karnego, Warszawa 2015; M. Królikowski, Okoliczności wyłaczające bezprawność jako konstrukcja sprawiedliwości korygujacej, „CzPKiNP” 2010, z. 2, s. 23 i n.
}

rozstrzygnięcia w drodze rzetelnego procesu. To zaś nie jest wyłącznie domeną instrumentów i gwarancji procesowych, ale otwartości praktyków na wymogi warsztatowe dogmatyki prawa karnego.

\section{Metoda klasycznej analizy dogmatycznej}

Wzmiankowana jako pierwsza, klasyczna ${ }^{8}$ dla polskiej praktyki wymiaru sprawiedliwości metoda

8 Nie potrafię zresztą znaleźć dla niej dostatecznie trafnego określenia. Do pewnego stopnia jest to schemat „warszawskiej” szkoły prawa karnego, opiera się ona bowiem na niezwykle wpływowym - co zdumiewające do dziś - piśmiennictwie Igora Andrejewa, które stworzyło kanony interpretacji znamion zakazu, choć bez wątpienia wywodziło się z radzieckiej nauki prawa karnego oraz zamiaru otwarcia go na potrzeby realizacji doraźnych interesów politycznych. Późniejszy znakomity autor związany z Uniwersytetem Warszawskim, wieloletni I Prezes Sądu Najwyższego, Lech Gardocki był kontynuatorem tej metody, kierując się w mojej ocenie trzema założeniami, a mianowicie samodzielnością zakazu karnego, potrzebą syntetycznego ujmowania zasad odpowiedzialności oraz łatwości w obsłudze materiału nor- 
interpretacji karnistycznej mimo ewidentnej proweniencji komunistycznej nie traci na znaczeniu i jest w praktyce - jak mniemam - wiodącą konwencją myślenia o sposobach posługiwania się prawem karnym. Trzeba jej poświęcić relatywnie więcej uwagi względem trzech pozostałych. Wynika to z jej naturalnej atrakcyjności i minimalnej liczby publikacji, które pokazywałyby cechy pracy z materiałem normatywnym w tej metodyce argumentacji. Upraszczając, nawiązuje ona do koncepcji ustawowych znamion przestępstwa. Rozumiemy przez nie cechy zdarzenia, które muszą być udowodnione w postępowaniu karnym, aby można było stwierdzić, że ktoś dopuścił się przestępstwa. Dotyczyć one mogą zachowania się zewnętrznego sprawcy, skutku i okoliczności tego zachowania, samej osoby sprawcy oraz jego stosunku psychicznego do zdarzenia. Powinny być wyrażane, w wymiarze zalecenia dla ustawodawcy, za pomocą kategorii w miarę ścisłych, sprawdzalnych i dających się udowodnić w postępowaniu rozpoznawczym, tworząc w ten sposób zabezpieczenie przed dowolnością w ściganiu i karaniu obywateli. Tak to ustawowe znamiona stanowią zarys typu przestępstwa, który mieści się w dyspozycji przepisu części szczególnej Kodeksu karnego ${ }^{9}$ oraz w tych przepisach jego części ogólnej, które dopełniają dyspozycję określeniem strony podmiotowej przestępstwa i samego podmiotu oraz form stadialnych i zjawiskowych danego przestępstwa ${ }^{10}$.

matywnego, z przyzwoleniem na aplikację odpowiedzialności karnej bez dodatkowych amortyzatorów wynikających z zaawansowanego aparatu dogmatycznego. Kolejno Zbigniew Jędrzejewski poszerzył obraz teoretyczny bezprawia karnego, a Jarosław Wyrembak rozwinął argumentację dotyczącą interpretacji znamion. Ostatnimi czasy w piśmiennictwie metodę tę opisał na nowo, niezwykle dojrzale badawczo i twórczo, Sławomir Żółtek. Wydaje mi się, że metoda ta ma dla praktyki stosowania prawa karnego naturalną atrakcyjność zwłaszcza w logice procesu gromadzenia dowodów czy postępowania rozpoznawczego, stąd można wywodzić tezę o jej powszechności. Z pewnością kontakt $\mathrm{z}$ praktyką pozwala utwierdzić się w tym osądzie.

9 Ustawa z dnia 6 czerwca 1997 r. - Kodeks karny (tekst jedn. Dz.U. z 2019 r., poz. 1950, z późn. zm.).

10 Tak I. Andrejew, Polskie prawo karne w zarysie, Warszawa 1976, s. 107 i n.; L. Gardocki, Prawo karne, Warszawa 2015, s. 52 .
W podanym opisie uporządkowanie zagadnień nie jest przypadkowe - kolejność części kodeksowych myślowo jest odwrócona i skoncentrowana na identyfikacji elementów zewnętrznych czynu zabronionego, które przemawiają za wystąpieniem innych cech czynu oraz przestępstwa. O tym pisze się nawet wprost, wskazując, że przy analizie funkcji gwarancyjnej ustawowych znamion odnosimy się tylko do tych cech czynu, które są określone w ustawie, natomiast nie do tych, które ustalane są w drodze wykładni. Co więcej, niektóre właściwości czynu są domniemane - jak w przypadku związku przyczynowego między zachowaniem się sprawcy a skutkiem, czy też szczególnym obowiązkiem działania sprawcy odpowiedzialnego za zaniechanie $^{11}$ - zaś zagadnienia związane z przypisywalnością (obiektywną) czynu zabronionego znajdują się na dalszym planie. Umożliwia to zgeneralizowanie powiązań między sprawcą a czynem, które przyjmuje się za wystarczające do uznania danej osoby za sprawcę przestępstwa w konkretnych przypadkach.

$\mathrm{Z}$ tej perspektywy, co więcej, widoczne w literaturze polskiej ostatnich lat rozważania dotyczące normy prawnokarnej i jej wpływu na struktury odpowiedzialności uważa się w zasadzie wyłącznie za nowy, w zasadzie pozbawiony wartości sposób opisywania tradycyjnych zagadnień prawnokarnych ${ }^{12}$. Można uzupełnić to jeszcze takim krytycznym spostrzeżeniem, że tego rodzaju prace nie mogą ze względu na swoje skomplikowanie i stosunkowo autonomiczny język być realnie dostępne dla praktyków, zwłaszcza śledczych i orzeczników. Każdy, kto próbował przed sądem rejonowym, gdzie orzeka dwóch sędziów bliskich stanowi spoczynku, wyjaśnić obiektywne przypisanie skutku przy zaniechaniu gwaranta, rozstrzygające o braku odpowiedzialności oskarżonego - a przyznam się, że przynajmniej raz próbowałem - nie może całkiem zapoznać tej konstatacji.

Omawiana metoda koncentruje się następnie wokół wykładni tych przepisów, które wyznaczają zakres kryminalizacji, a więc głównie przepisów części szczególnej Kodeksu karnego. Jako wiodącą metodę przyjmuje się wykładnię językową odwołującą się do znaczenia słów użytych w tekście ustawy, akcentując

11 I. Andrejew, Polskie prawo..., s. 108.

12 L. Gardocki, Prawo karne..., s. 35. 
możliwość osiągnięcia tą drogą największej dostępności treści zakazu dla nieprawników. Odwoływanie się do wykładni sięgającej do celu lub sensu przepisu, czy też jego miejsca w systemie prawa, powinno mieć w myśl zwolenników tej metody miejsce tylko wtedy, gdy wykładnia językowa dopuszcza różne warianty rozumienia przepisu ${ }^{13}$. Dotyczy to zarówno sytuacji, w których cechy zachowania się łatwo stwierdzić w sposób obiektywnie sprawdzalny, jak i tych, kiedy ich aktualizacja wymaga weryfikacji w świecie ocen i wartościowań. Ma to szczególne znaczenie w przypadku rozróżnienia znamion ostrych - w miarę bezpiecznych gwarancyjnie - oraz nieostrych, które nie dają wyraźnego zakresu czynu karalnego, ujmując go w płynny i zamazany sposób. Podobnie dzieje się z miękkimi dyrektywami zaostrzającymi wymiar kary, które w istocie modyfikują typy przestępstw (np. występek chuligański).

W świetle tych priorytetów zagadnienia związane z częścią ogólną w znacznej mierze są powiązane z wykładnią znamion, zwłaszcza wobec ostatnich poważnych publikacji w tym zakresie ${ }^{14}$. Znaczna część orzecznictwa sądów powszechnych, ale i Sądu Najwyższego, pozostaje niezmiennie pod dużym wpływem tego kierunku metodologicznego przede wszystkim ze względu na nabyty przez lata pracy warsztat dogmatyczny i orzeczniczy, a także kształt przepisów procesowych. Nie wydaje się jednak, by wynikało to z szerokiego omówienia i świadomego przyjęcia rozbudowanych założeń metody dogmatycznej, ale raczej z naturalnej jej cechy, aprobowanej w judykaturze, jaką jest dominacja analizy przypadków, nie zaś opisywanie zasad przemyślanego, spójnego systemu zasad odpowiedzialności karnej. O ile bowiem w przypadku omawianej poniżej metodologii struktur normatywnych mamy w analizie konkretnego przypadku modelowo do czynienia z refleksem myślenia systemowego, o tyle metoda analizy dogmatycznej wynika z myślenia topicznego ${ }^{15}$, a zatem punkto-

13 L. Gardocki, Prawo karne..., s. 33-34.

14 Zob. przykładowo S. Żółtek, Znaczenie normatywne...; M. Budyn-Kulik, Umyślność w prawie karnym i psychologii. Teoria i praktyka sądowa, Warszawa 2015.

15 J. Stelmach, B. Brożek, Metody prawnicze. Logika-analiza - argumentacja - hermeneutyka, Kraków 2004, s. 166 i n. wego i względnego, związanego z funkcjonalnością aplikacji zakazów wyrażonych w części szczególnej Kodeksu karnego, prowadzącej niemal do tego, że strukturę przestępstwa wyznacza konkretny zespół znamion. W sposób naturalny praktyka stosowania prawa skłania do przyjmowania tej metody analizy spotykanych w niej problemów - pozwala na przekonanie, że większość z nich nadaje się do rozwiązania za pośrednictwem w miarę prostych i niesystemowych narzędzi, które jednak w rzeczywistości są elementem ogólniejszej metody dogmatycznej i warsztatu wykładniczego ${ }^{16}$, ale jednocześnie nie wymagają argumentowania "przez system” - w tym ogólnym znaczeniu, rozumianym jako demokratyczny porządek prawny, i w tym bardziej szczególnym znaczeniu, jako zespół zasad odpowiedzialności karnej.

Do założeń przyjmowanych przez autorów pozostających w tym kierunku warsztatowym należy przede wszystkim przekonanie, że całość wypowiedzi normatywnej - w części wyznaczającej bezprawność oraz przewidującej karalność danego zachowania posiadającego cechy typu czynu zabronionego - określanej niekiedy jako bezprawność karna, jest wyznaczana w sposób dominujący, a nawet wyłączny przez przepis prawa karnego, ewentualnie to konkretne znamię blankietowe lub operacja wykładnicza "pod” typem ${ }^{17}$ może dopiero doprosić bezprawność zewnętrzną względem zakazu lub znieść bezprawność karną jako wynik kazuistycznej racjonalizacji. Bezprawność karna jest zatem wyrazem samodzielnego wartościowania ustawodawcy. Nie można jej sprowadzić względem bezprawia ogólnego do roli swego rodzaju aneksu, w którym przewidziano przypadki

16 Z. Jędrzejewski przytacza nawet ironiczną wypowiedź B. Schünemanna, który twierdzi, że dążenie do ujęć systemowych, w tym przede wszystkim systematyka przestępstwa, kwalifikowania różnorodnych elementów, także elementów przestępności czynu, w jednoznacznie określone i wzajemnie uporządkowane kategorie wykształconemu laikowi wydaje się często dziwaczne, studentowi niezrozumiałe, a praktykowi po prostu zbędne (Z. Jędrzejewski, Bezprawność..., s. 24-25). Zob. także C. Roxin, Strafrecht. Allgemeiner Teil, Bd. I, Grundlagen. Der Aufbau der Verbrechenslehre, München 2006, s. 211-214.

17 L. Gardocki, Pozaustawowe źródła... 
karalności za naruszenie ogólnosystemowych norm sankcjonowanych ${ }^{18}$.

Jak zaznaczono, bezprawność wywodzona z systemu jest ujawniana w treści normy sankcjonowanej dekodowanej z treści zakazu karnego zwłaszcza w tych przypadkach, kiedy ustawodawca otwiera dany typ czynu zabronionego przez użycie znamion prawnie ocennych ${ }^{19}$. Bezprawność konstruowana w ten sposób przez uwzględnianie norm spoza typu jest procesem selekcji zachowań w obrębie typu, z których tylko te, które wpierw zostały uznane za bezprawne w świetle innego, niekarnego zespołu norm, są następnie wartościowane w perspektywie bezprawności karnej. Ujmując to od strony opisu znamion negatywnych, „obca bezprawność" stanowi cechę eliminującą część zachowań samoistnie realizujących pozostałe znamiona typu, nie ma też charakteru okoliczności legalizującej, zaś sama owa obca bezprawność musi być jako znamię objęta zamiarem ${ }^{20}$.

Jest to spostrzeżenie w równym stopniu teoretyczne, co praktyczne. Przecież właściwie tylko teoretycznie można powiedzieć, że w przypadku każdego aktu stosowania prawa dochodzi do wyznaczenia pełnej normy przez sięganie do wszystkich określających ją źródeł, zarówno ustawowych, jaka i pozaustawowych. Nie jest chyba nawet oczywiste to, że w praktyce dokonywana jest rzeczywista analiza całości zespołu znamion, bo raczej spotykamy tu rozumowe domniemania ich wypełnienia w przypadku ukazania się w zachowaniu sprawcy $\mathrm{w}$ procesie dowodowym postępowania przybliżonego do typowego, w zgodzie ze znaczeniem pojęć użytych w ustawie.

Oczywiście jest to metoda o konkretnych założeniach i walorach naukowych. Należy do nich założenie o pożądanej i faktycznej fragmentacji systemu odpowiedzialności karnej - o ile oczywiście istotna część zagadnień pozostaje w obrębie nauki o przestępstwie wyrażonej w konstrukcjach części ogólnej powiązanej z trzema pierwszymi rozdziałami Kodeksu kar-

18 Z. Jędrzejewski, Bezprawność..., s. 146; zob. również T. Kaczmarek, O bezprawności i strukturze przestępstwa, „Państwo i Prawo" 2010, nr 7, s. 88 i n.

19 W. Wolter, Klauzule normatywne w przepisach karnych, „Krakowskie Studia Prawnicze” 1969, nr 2, s. 5 i n.

20 S. Żółtek, Znaczenie normatywne..., s. 314-315. nego, o tyle niekiedy to $\mathrm{z}$ analizy przypadków części szczególnej, niejako na zasadzie indukcyjnej, wywodzone są konstrukcje zaliczane następnie do ogólnych zasad odpowiedzialności. Doskonałym przykładem tego zjawiska jest idea zamiaru quasi-ewentualnego, wywiedzionego w związku z typem czynu zabronionego, względem którego przyjęcie standardowego testu umyślności pozbawiłoby daną decyzję kryminalizacyjną w przyjętym kształcie sensu ${ }^{21}$, albo przyzwalanie na redukowanie strony podmiotowej do formy zbliżonej do zamiaru ogólnego. Innym podobnym kierunkiem może być przyjmowanie substytutu sprawstwa pośredniego w przypadku czynów nieumyślnych w związku ze skutkowym ujęciem znamion czasownikowych czynu zabronionego. Dodatkowo wiele problemów proponuje się rozwiązywać w idei rzetelnej wykładni znamion typu, zakładając ich zawężanie, z powołaniem się na charakter dobra prawnego, stopień jego subiektywizacji czy obiektywizacji ${ }^{22}$, cel danej kryminalizacji czy też konieczność stałej korekcji racjonalności zakresu danego zakazu karnego. Dobro to nie jest przy tym traktowane najczęściej jako znamię czynu zabronionego w ścisłym tego słowa znaczeniu $^{23}$, o ile nie zostało wprost wypowiedziane jako

21 Zob. poglądy I. Andrejewa i L. Gardockiego w ich cytowanych powyżej podręcznikach. Pojęcie zamiaru quasi-ewentualnego powstało w celu scharakteryzowania strony podmiotowej czynu, w sytuacji gdy sprawca chce osiągnięcia określonego celu, ale nie ma pewności, że mu się to uda. Koncepcji zarzucano, że odnosi stronę podmiotową do wyizolowanego kontekstu znamienia czasownikowego, że jest po prostu odmianą zamiaru ewentualnego. W istocie jednak klasyczne konstrukcje kodeksowe są zmodyfikowane do tego stopnia, że niepewność co do znamienia statycznego (a zatem brak świadomości realizacji znamion) nie stanowi przeszkody w działaniu w zamiarze bezpośrednim godzenie dotyczy jednego ze znamion i nie przewartościuje zasadniczo chęci realizacji istoty czynu.

22 Z. Jędrzejewski, Zgoda dysponenta dobrem a struktura przestępstwa, „Prokuratura i Prawo” 2008, nr 5, s. 37 i n.; K. Szczucki, Rola zgody w strukturze przestępstwa na przykładzie przestępstwa zgwałcenia, „CzPKiNP” 2011, z. 1, s. 31-58.

23 Tak S. Żółtek, Znaczenie normatywne..., s. 378; por. W. Wróbel, Konstrukcja kontratypu..., s. 372. 
znamię ustawowe ${ }^{24}$. Najbliższy właściwej roli dobra prawnego w wykładni zakazów karnych w omawianej metodologii jest w mojej ocenie pogląd wskazujący na to, że dobro prawne urzeczywistnia niezwykle silną dyrektywę interpretacyjną o wymiarze funkcjonalnym, która nakazuje przyjęcie takiego znaczenia dekodowanych znamion, że przy uwzględnieniu ograniczeń gwarancyjnych dojdzie do rekonstrukcji normy optymalnie zabezpieczającej to dobro na drodze zakazu karnego (tzw. dyrektywalna rola dobra prawnego) ${ }^{25}$. Dodać należy również i to, że w konsekwencji reguły postępowania $z$ dobrem nie wyznaczają zakresu bezprawności - ani tej ogólnej, ani tej wyrażonej w teleologii prawa karnego. Ich naruszenie nie prowadzi do aktualizacji normy sankcjonowanej wyrażonej w typie, dopiero bowiem materialne odniesienie się do celu zakazu karnego związanego z funkcją ochronną danego dobra prawnego na tę aktualizację pozwala. Jeszcze inaczej rzecz ujmując, o ile dobro wskazuje płaszczyznę, na jakiej należy dekodować reguły postępowania $z$ dobrem, o tyle nie wymaga ich naruszenia dla stwierdzenia, że dobro doznało uszczerbku.

Kolejna istotna cecha omawianego sposobu rekonstrukcji bezprawności karnej polega na poszukiwaniu jej odrębności gałęziowej. Wskazuje się na to, że bezprawność skutku i niebezpieczeństwa naruszenia dobra jest właściwa dla prawa cywilnego, w obrębie zaś prawa karnego tą metodą można maksymalnie wyznaczyć zręby zakazów wyrażających typy czynów zabronionych $\mathrm{z}$ winy nieumyślnej. Tymczasem podstawową nicią, wokół której nanizana jest bezprawność karna, stanowi umyślny zamach na dobro, stąd w obszar bezprawności włączone są zarówno momenty przedmiotowe, jak i podmiotowe, $w$ tym także zamiar. Powoduje to istotne przesunięcie w metodzie rozpoznania znamion typu czynu, gdzie dominuje stwierdzanie wystąpienia obiektywnych znamion szczegółowych typu czynu zabronionego w zachowaniu się sprawcy oraz ich odbicia w jego świadomości najczęściej wywodzone $\mathrm{z}$ uprawdopodobnienia dokonywanego przez realizację znamion przedmiotowych.

$\mathrm{W}$ omawianej metodzie rezygnuje się często $\mathrm{z}$ dodatkowych schematów dowodowych, które miałyby np.

24 L. Gardocki, Prawo karne..., s. 94.

25 S. Żółtek, Znaczenie normatywne..., s. 381-382. zapobiegać wywodzeniu zamiaru ze skutku czy wartościowaniu momentów podmiotowych na różnych etapach weryfikacji podstaw odpowiedzialności karnej danej jednostki. Metodę tę cechuje raczej tendencja do łączenia materii rozkładanych w innych metodach na rożne warstwy systematyki przestępności, zaś modyfikacje dowodowe są dopuszczane ze względu na różnorodność znamion ustawowych typów czynów zabronionych. W tej logice pojawiają się orzecznicze modyfikacje typów czynów zabronionych, które rekonstruują interes publiczny, niekiedy łączony z interesem wymiaru sprawiedliwości, jako wiodącą dyrektywę wykładniczą (zob. np. ekstensywne odczytywanie zakazu prania brudnych pieniędzy lub odpowiedzialność z tytułu art. $233 \$ 1$ la k.k.) albo przyjmują uproszczenia w rekonstrukcji zespołu znamion z powodów racjonalizacji zakazu, któremu chce się nadać samodzielną, regulacyjną funkcję (np. identyfikacja oszustwa przez niewyjawienie standingu firmy).

Metoda ta jest również niekiedy nadmiernie zniewolona konstrukcją znamion danego typu, które pozbawiają praktykę stosowania prawa odpowiedniej racjonalności wynikającej z reżimu ścisłej aplikacji ogólnych zasad odpowiedzialności karnej. Dotyczy to zwłaszcza takich zespołów cech ustawowych czynu zabronionego, które włączyły w obszar znamienności typu czynu zabronionego konstrukcje właściwe dla części ogólnej Kodeksu karnego, takiego jak formy zjawiskowe czy stadialne. Tego rodzaju sposoby typizacji spotyka się najczęściej w dowodowo pragmatycznie zaprojektowanej kryminalizacji lub przy implementacji unijnego prawa karnego, w praktyce podyktowane sposobem kontroli zupełności dokonanej implementacji przez Komisję Europejską, którą łatwiej usatysfakcjonować prostym skopiowaniem opisu czynu zawartego w decyzji ramowej lub dyrektywie niż zestawianiem pola kryminalizacji rekonstruowanego zakazu karnego powiązanego z ogólnymi postaciami realizacji znamion przewidzianymi w części ogólnej Kodeksu karnego, takimi jak podżeganie czy pomocnictwo. Zresztą niekiedy zawarte w nich wymogi strony podmiotowej okazują się zbyt wysokie, by w pełni pokryć wymagane przez prawodawcę unijnego pole kryminalizacji.

W przypadkach tego rodzaju typów czynów zabronionych nie ma też możliwości pełnego stosowania systemu zasad odpowiedzialności karnej, jeżeli uznać, 
że ustawodawca, wprowadzając szczegółowe cechy znamienności typu czynu zabronionego, dokonał ich modyfikacji. Niektórzy nie tylko akceptują ten stan rzeczy, ale wręcz aprobują go, wskazując na prawo ustawodawcy do czynienia wyjątków, tj. tylko częściowego opierania się na ogólnych regułach przypisania odpowiedzialności karnej czy wręcz celowego ich pominięcia w konstrukcji typu czynu zabronionego ${ }^{26}$. $\mathrm{Z}$ tego także powodu formułowane jest domniemanie ochrony dobra prawnego postrzegane przez pry- gwarancyjnych. Z tego powodu nacisk kładziony jest na zakres kryminalizacji wyprowadzany z wykładni językowo-logicznej i akcentowana jest przewaga znaczenia znamion przedmiotowych w procesie ustalania podstaw odpowiedzialności karnej jednostki. Z drugiej strony metoda ta dopuszcza działania zawężające przesłanki odpowiedzialności karnej wobec zakresu znamion przez modyfikację celu ochronnego dóbr prawnych $^{28}$. Nie proponuje jednak jednolitych kryteriów takiej modyfikacji, poruszając się wokół pojęć

\section{Istotną cechą klasycznej metody analizy} przepisów prawa karnego jest wysoka jej zmienność i zdolność do uzyskiwania adekwatności do celów kryminalno-politycznych wyrażonych w kreacji zakazów karnych.

zmat tak, a nie inaczej ukształtowanych zakazów karnych zawartych w części szczególnej i niepoddawanie zakresu kryminalizacji weryfikacji przez rozumowanie ogólnosystemowe, jako że wykazuje ono tendencje do zbyt szerokiej ingerencji karnoprawnej lub zbyt dużej arbitralności ${ }^{27}$.

Dalszą istotną cechą wskazanej metody analizy przepisów prawa karnego jest wysoka jej zmienność i zdolność do uzyskiwania adekwatności do celów kryminalno-politycznych wyrażonych w kreacji zakazów karnych. Niemniej nie jest to cecha jednowymiarowa. Z jednej strony metoda ta nakazuje wiązać odpowiedzialność karną z konkretnie występującym jako zdarzenie realne zachowaniem sprawcy starannie rekonstruowanym przez znamiona typu czynu zabronionego i w znamionach tych poszukuje względów

26 S. Żółtek, Znaczenie normatywne..., s. 358; Z. Jędrzejewski, Bezprawność..., s. 146-147; A. Spotowski, Karalność w razie braku zagrożenia dobra prawnego, „Państwo i Prawo” 1988, nr 7, s. 76.

27 S. Żółtek, Znaczenie normatywne..., s. 395-396. „społecznej adekwatności zakazu”, zmiennej „społecznej szkodliwości czynu", czy intuicji co do racjonalności polityczno-kryminalnej. Jest to traktowane jako argument za tą metodą, wobec tego, że nie musi ona domykać zespołu ogólnych zasad odpowiedzialności karnej w poszukiwaniu ich spójności przez powoływanie do życia rozwiązań ściśle artefaktycznych, wobec obiektywnej rzeczywistości nieprawdziwych ${ }^{29}$. Pozwala dostatecznie rozróżnić uzasadnienie instytucji prawnych, wobec których nie wymusza ujednolicenia założeń, jak to się dzieje w przypadku dyskusji na temat okoliczności kontratypowych, które w przeciwieństwie do teorii struktur normatywnych nie muszą być - w ocenie zwolenników referowanej

28 L. Gardocki, Prawo karne..., s. 94; R. Zawłocki (w:) Kodeks karny. Część ogólna, red. M. Królikowski, R. Zawłocki, Warszawa 2017, uwagi do art. 115.

29 A. Zoll pisze wprost o logicznym prius normy sankcjonowanej lub o konieczności stworzenia specjalnej normy sankcjonowanej w sytuacji jej braku - tenże, O normie prawnej... 
metody - sprowadzane do konfliktu interesów prawnych, a zatem kryteriów przede wszystkich utylitarnych, ale uzyskują uzasadnienie pluralistyczne, które pozwala właściwie oddać sens i skutki danej instytucji prawnej. Dobrym przykładem skutków konkurencji metody struktur normatywnych oraz klasycznej dogmatyki jest rekonstrukcja istoty i znaczenia kolizji obowiązków, które albo zostaną sprowadzone do matrycy stanu wyższej konieczności i w przypadku kolizji obowiązków równej wartości powinny prowadzić do wyłączenia winy, ale nie bezprawności, albo będą wynikały z zasady impossibilium nulla obligatio est, a zatem kolizja ta nie może wyrazić się w żadnym razie w cesze bezprawności, albo - co będzie już antycypacją trzeciej metody - przybliży się do sytuacji subiektywnego postrzegania kolizji i niezdolności do właściwego wartościowania, skutkującej błędem co do znamienia lub prawa.

Jak mniemam, przedstawiciele omówionej metody uważają, że podstawowy walor dowodowy w prezentowanym przez nich podejściu do analizy prawnokarnej wynika z modelu dokonywania dokładnej oceny konkretnej sytuacji w odniesieniu do konkretnych typów czynów zabronionych. Różnorodność struktur materiału prawnego jest bowiem na tyle bogata i poddana wartościowaniu związanemu z funkcją zakazów karnych, że uporządkowane wokół niewielkiej liczby kategorii przewodnich zasady odpowiedzialności karnej fałszują obraz właściwej aplikacji zakazu karnego do badanej sytuacji, wymagając stosowania jakichś abstrakcyjnych kategorii rozumowania, najczęściej wiązanych z konsekwencjami wykładni systemowej, zarówno w obrębie prawa karnego, jak i związków prawa karnego z pozostałym materiałem normatywnym.

To, co wydaje się być zaletą, otwiera omawianą metodę na wgląd krytyczny. Redukcja obszaru części ogólnej względem części szczególnej prawa karnego powoduje, że funkcja gwarancyjna systematyki przestępstwa, wbrew częstym deklaracjom ${ }^{30}$, schodzi na plan dalszy. Prawdą jest bowiem, że formalno-dogmatyczna metodologia i separacja struktury przestępstwa od teleologii prawa karnego, w tym wyrażanej wizji polityczno-kryminalnej, stanowi jako taka rodzaj

30 Z. Jędrzejewski, Bezprawność..., s. 83 obrony przed wpływami ideologicznymi w procesie stosowania prawa karnego. Strukturalnie włączone w system interpretacji karnistycznej rekonstrukcje systemowe wynikające z założeń demokratycznego państwa prawnego gwarancje te zwiększają. Dopiero ingerencja ideologiczna przy założeniach systemowych porządku prawnego, przewartościowanie znaczenia demokratycznego państwa prawa względem funkcji państwa czy dekompozycja wzorców konstytucyjnych i procesu kontroli konstytucyjności stanowienia i stosowania prawa uczynić mogą z klasycznej metody dogmatycznej w prawie karnym narzędzie o relatywnie wyższym stopniu gwarancyjności niż metody akcentujące konieczność odniesień systemowych lub dostrzegające w ogólnych zasadach przypisania sprawstwa mechanizmy ograniczające ekspansję zakazu karnego poza jego właściwą funkcję. W pozostałych przypadkach strukturze przestępstwa i systemowi zasad odpowiedzialności karnej należy w ramach omawianej metody przypisać w zasadzie funkcję gwarancyjną, ale na zasadzie negatywnej, tj. przeszkody przed możliwymi przerostami potrzeby ukarania, wyrażającej się nie tylko w interpretacji rozszerzającej znamion typu czynu zabronionego, ale także w postaci form rozszerzonej odpowiedzialności karnej.

\section{Metoda systemowych struktur normatywnych w prawie karnym}

Ten rodzaj metody polega na dominacji warsztatu odwołującego się do ogólnych struktur określających podstawy odpowiedzialności karnej w analizie materiału prawnego ${ }^{31}$. Co więcej, w procesie rekonstrukcji i wyjaśnianiu zakresu aplikacji prawa karnego dominuje tu rozróżnianie między pojęciami przepisu i normy prawnokarnej - z założeniem, że to w wyodrębnieniu kategorii normatywnych wyrastających $\mathrm{z}$ wyprowadzania $\mathrm{z}$ warstwy tekstowej wypowiedzi powinnościowych należy szukać narzędzi do zgodnego

31 Szeroko na ten temat: P. Kardas, O relacjach...; por. J. Giezek, Metoda prawa karnego. O budowaniu „karnistycznych” teorii naukowych oraz ich wpływie na odpowiedzialność karną, „Wrocławskie Studia Erazmiańskie” 2014, t. 8, s. 29-55; tenże, O możliwości naukowego uzasadnienia zmiany modelu odpowiedzialności karnej, „Państwo i Prawo” 2017, nr 2, s. $3-19$. 
$\mathrm{z}$ celem prawa karnego stosowania regulacji z tego zakresu $^{32}$. Warto jest wskazać na kilka wiodących cech tego podejścia warsztatowego w pracy dogmatycznej w obszarze prawa karnego.

Po pierwsze, jest to postępowanie opierające się przede wszystkim na metodzie rozumowania systemowego. Celem teoretycznego wysiłku dogmatycznego przedstawicieli tego kierunku jest bowiem zbudowanie spójnego systemu normatywnego tworzącego fundamenty zasad odpowiedzialności karnej w ogóle i w konkretnym przypadku³. Model ten, wobec mnogości problemów związanych ze stosowaniem różnorodnie ukształtowanych znamion typów czynów zabronionych, jak i logicznych konsekwencji przyjętych założeń, nie może wytrzymać wszystkich weryfikacji związanych z krytycznymi, pogranicznymi dla wiodących zasad systemu instytucjami, takimi jak usiłowanie nieudolne, urojenie znamienia kontratypu czy im podobne. Dla uzyskania spójności wymaga się zatem przyjęcia na poziomie systematyki ogólnej rozwiązań szczególnych, „zamykających” nieszczelności przy scalaniu składowych systemu zasad odpowiedzialności karnej, albo rozwiązywania problemów zasad odpowiedzialności karnej przy akceptacji punktowego złamania części założeń systemowych, jak ma to miejsce w przypadku wtórnego błędu co do prawa czy podwójnej funkcji zamiaru. Kierunek ten prawidłowo reasumuje przekonanie, że to kompleksowa teoria dekodowanych z przepisów prawa karnego norm stanowić powinna podstawę badań nad prawem karnym, samo zaś opracowanie problematyki dających się odczytać z przepisów prawa karnego norm może stanowić podstawę prac nad stworzeniem systemy dogmatycznego nauki o przestępstwie. Co istotne, wyraża się przekonanie, że w problematyce normy należy szukać nie tylko podstaw rozwiązania kwe-

32 R. Dębski, Jeszcze o normie..., s. 117; zob. również W. Wróbel, A. Zoll, Polskie prawo karne. Część ogólna, Kraków 2010, s. 108-109; M. Małecki, Między bezprawnością, karalnościa $i$ wina (na marginesie artykułu prof. Zbigniewa Jędrzejewskiego), „CzPKiNP” 2017, z. 3, s. 76-94.

33 J. Majewski, Czy idea tak zwanej wtórnej legalności się broni, „Nowa Kodyfikacja Prawa Karnego”, t. XLIII, Księga jubileuszowa Profesora Tomasza Kaczmarka, red. J. Giezek, D. Gruszecka, T. Kalisz, Wrocław 2017, s. 401-420. stii teoretycznoprawnych, ale probierza właściwego stosowania prawa karnego ${ }^{34}$.

Po drugie, wskazana metoda cechuje się konsekwentnie przewagą rozważań nad zagadnieniami zaliczanymi do tzw. części ogólnej prawa karnego. Obejmuje to zarówno teorię zasad odpowiedzialności karnej, jak i jej ekspansywność względem części szczególnej Kodeksu karnego, polegającą na wyprowadzaniu przed nawias, w którym mieszczą się zespoły zakazów karnych, cech wspólnych. Niekiedy przyjmują one nawet postać znamion ogólnych czynu zabronionego, jak dzieje się to w przypadku niesprawczych postaci popełnienia czynu zabronionego. Kiedy indziej rodzą dla prawa karnego pewne nietypowości w obrębie danych instytucji ogólnych, jak ma to miejsce w przypadku tezy o tzw. względnej subsydiarności obrony koniecznej.

Po trzecie, w zdecydowanej większości przedstawiciele tego kierunku myślenia o prawie karnym proponują rozwiązywanie konkretnych przypadków związanych ze stosowaniem przepisów części szczególnej Kodeksu karnego przez właściwe stosowanie instytucji zaliczanych do części ogólnej. Do takich zagadnień o szczególnie kontrowersyjnym i wiążącym rozwiązania z zakresu dogmatyki znamion można zaliczyć m.in. problematykę wyznaczania tożsamości czynu ${ }^{35}$, wyłączania wielości ocen w prawie karnym ${ }^{36}$ czy niesprawczych postaci współdziałania w czynie zabronionym. Dzieje się tak mimo świadomości tego, że przez lata polska dogmatyka prawa karnego w zakresie analiz dotyczących zasad odpowiedzialności karnej radziła sobie w pełni bez odwoływania się do struktury i treści dekodowanych z przepisów prawa karnego norm, poszukując satysfakcjonującego rozwiązania problemów na drodze rozumowania formalno-logicznego.

Wskazana metoda opiera się na założeniu, że bezprawność oraz wina w rozumieniu zarzucalności

34 A. Zoll, O normie prawnej..., s. 73; P. Kardas, O relacjach..., s. 10. Por. również Ł. Pohl, Prawo karne. Wykład części ogólnej, wyd. 1, Warszawa 2010, s. 73.

35 J. Majewski, „Ten sam czyn” jako jedna z przesłanek kumulatywnej kwalifikacji (w:) Zbieg przepisów oraz zbieg przestępstw w polskim prawie karnym, red. tegoż, Toruń 2006, s. $39 \mathrm{i} \mathrm{n.}$

36 M. Tarnawski, Zagadnienia jedności i wielości przestępstw, Poznań 1977; P. Kardas, Zbieg przepisów ustawy w prawie karnym, Warszawa 2011 
danego postępowania nie poddają się szczególnemu wartościowaniu karnemu. Zatem to nie zakaz karny wyznaczy normę sankcjonowaną, czy innymi słowy powinność określonego postępowania, i nie on rozstrzygnie o wadliwości wyboru danej drogi postępowania, w szczególności o tym, czy można było wymagać dania posłuchu tej normie i czy dokonany przez sprawcę wybór był naganny. Metoda ta narzuca także określony porządek rozumowania, w którym po badaniu naruszenia zakazu określonego postępowania, wyrażonego w innej niż sama prawnokarna gałąź prawa, następuje ocena realizacji przez sprawcę istoty czynu zabronionego, w szczególności ustawowych znamion strony przedmiotowej i podmiotowej, a następnie etap wartościowania związany z celem odpowiedzialności karnej, czyli badanie stopnia ciężaru czynu i zasadności stosowania w danym wypadku sankcji karnej. W procesie ustalania powinności danego zachowania związanego z normą sankcjonowaną, uwarunkowaną nie tylko samymi wypowiedziami ustawowymi, ale i racjonalnością obrotu prawnego, a zatem ryzykiem obrotu, zasadami ostrożnego postępowania z dobrami prawnymi, zakresem pożądanej odpowiedzialności za wywołane następstwa, występuje zespół domniemań materialnoprawnych, wyrażających się w przyjęciu zdolności jednostki do zawinienia. $\mathrm{Z}$ tego też powodu powrót do tego - niepoddanego wartościowaniu związanemu z celem funkcjonowania prawa karnego - zespołu argumentacji następuje na etapie ostatniej warstwy przestępności, a mianowicie badania, czy nie wystąpiły okoliczności subiektywne "obalające" to domniemanie. Zresztą ze względu na nieprocesowy charakter tego domniemania lepiej być może byłoby mówić o korekcji wyjściowych podstaw odpowiedzialności w danym przypadku niż o regule obalania domniemania.

$\mathrm{W}$ polskim piśmiennictwie ostatnich lat rozwinięto wpływową normatywną analizę prawa karnego i podstaw odpowiedzialności karnej. Jako programowe należy uznać stanowisko, że „dopiero prawidłowe, konsekwentne rozwinięcie tej problematyki (tj. zainteresowania problematyką normy prawnej w nauce prawa karnego) stanowić może podstawę prac nad stworzeniem systemu dogmatycznego nauki o przestępstwie. W problematyce normy szukać należy też podstaw rozwiązań całego szeregu zupełnie podsta- wowych zagadnień prawa karnego, mających nie tylko znaczenie teoretyczne, lecz decydujących o właściwym stosowaniu prawa" ${ }^{37}$.

Również obowiązujący Kodeks karny niejako siłą rzeczy przejął wypracowane w ten sposób poglądy na temat fundamentów odpowiedzialności karnej, zasad jej określania, jej granic, w końcu - podstawowych figur prawnokarnych, takich jak bezprawność, karygodność, pojmowanie kontratypów, winy itp. Przejęła je w niektórych dziedzinach judykatura, co widać w szczególności w rozwijającej się linii orzeczniczej w zakresie tzw. obiektywnego przypisania skutku.

W ocenie autorów tego kierunku prawo karne w zasadzie nie odpowiada na pytanie o bezprawność jakiegoś zachowania - czynią to inne dyscypliny prawne. Zakazy prawa karnego, dopóki nie zostaną uzgodnione z całością systemu prawnego, nie rozstrzygają samodzielnie o ocenie braku legalności. Chodzi tu głównie o wymiar kryminalno-polityczny, choć trudno zaprzeczyć, że musi to także znaleźć odzwierciedlenie w konstrukcji normatywnej. Dzieje się tak przede wszystkim dlatego, że prawo karne nie pełni roli organizującej porządek prawny, a w każdym razie funkcja ta nie jest dla prawa karnego konstytutywna. Prawo karne pełni funkcję zabezpieczającą porządek prawny organizowany regułami względem niego pierwotnymi, dlatego rekonstruowanie z przepisu karnego normy sankcjonowanej jest dla prawa karnego czymś ubocznym. Owa służebna funkcja decyduje o subsydiarności prawa karnego.

Prawo karne ustala, jakie normy podlegają ochronie prawnokarnej, tj. jakie zachowania sprzeczne z normą sankcjonowaną są karalne. W tym celu określa przesłanki karalności, opisując warunki, w których dochodzi do aktualizacji obowiązku wymierzenia sankcji. Ostatecznie funkcją przepisu karnego jest określenie

37 Do prac wyjściowych zaliczano: A. Zoll, O normie prawnej..., s. 69-70; W. Wróbel, Znamiona normy sankcjonowanej $i$ sankcjonującej w przepisie prawa karnego, Kraków 1992, rozprawa doktorska niepubl.; tenże, Struktura normatywna...; tenże, Relacyjne $i$ wartościujace ujęcie bezprawności w prawie karnym, „Przegląd Prawa Karnego” 1993, nr 8 (koncepcja bezprawności nieco odmienna wobec poglądów A. Zolla); J. Majewski, Prawnokarne przypisanie skutku przy zaniechaniu, Kraków 1997. 
czynu karalnego, jego typizacja, która pozwala na odgraniczenie go od czynów niekaralnych (niezależnie od tego, czy są one bezprawne, legalne czy też w ogóle niepodlegające kwalifikacji prawnokarnej) lub od innych czynów karalnych. Przepis prawa karnego określa ostatecznie karę, jaka ma być orzeczona w przypadku naruszenia normy sankcjonowanej.

W konsekwencji w obrębie systematyki przestępności następuje podział znamion przestępstwa na znamiona określoności czynu, których realizacja powoduje naruszenie normy sankcjonowanej i w konsekwencji bezprawność zachowania, oraz znamiona karalności (czyli znamiona typu przestępstwa), których wypełnienie skutkuje aktualizacją obowiązku do ukarania sprawcy czynu. Te pierwsze mogą być wypowiedziane $\mathrm{w}$ ustawie (znamiona ustawowe), ale nie muszą, a mimo to wpływają na ocenę bezprawności. Do tego rodzaju znamion należy m.in. naruszenie dobra prawem chronionego lub stworzenie takiego niebezpieczeństwa, czy naruszenie reguł postępowania $\mathrm{z}$ dobrem (reguł ostrożności) - a więc zasadniczo znamiona przedmiotowe. Znamiona podmiotowe, umyślność lub nieumyślność, zaliczają się do znamion karalności.

Tam, gdzie rozróżnienie płaszczyzny bezprawności od poziomu karalności jest trudne, wprowadza się zasadę, że karalność może opierać się na „nowej” szczególnej normie sankcjonowanej - wprowadzanej również przez regulację prawnokarną. Zabieg ten stanowi krytyczny punkt całej teorii. Ma to miejsce m.in. w przypadku podżegania lub pomocnictwa do określonego typu przestępstwa indywidualnego właściwego (tj. kiedy podmiot nie jest zdolny do naruszenia podstawowej normy sankcjonowanej - zob. art. 21 $\$ 2$ k.k.). Nawet jeśli uznamy, że w tym wypadku zakaz ma charakter złożony, sięgający bowiem do przepisu części szczególnej, to powołanie do życia nowej normy sankcjonowanej następuje na potrzeby karalności niejako niezależnie od wcześniej promowanej struktury zasad odpowiedzialności. Zasadne są tutaj wątpliwości o charakterze metodologicznym.

Analizując pojęcie normy sankcjonowanej, a więc tej, która rozstrzyga o bezprawności czynu, wskazać należy na dwa aspekty takiej normy: aksjologiczny oraz teleologiczny. Pierwszy oznacza dokonywanie wartościowania zachowania objętego normą sankcjonowaną, przy czym wartościowanie negatywne staje się podstawą do zakazu i ucieleśnia imperatyw określonego postępowania, który formułuje norma sankcjonowana. Jednakże sama bezprawność nie wynika jedynie z formalnej sprzeczności zachowania $\mathrm{z}$ treścią normy sankcjonowanej, lecz jest wynikiem samego wartościowania. Kryterium wartościowania ujemnego, które stanowi podstawę stanowienia zakazu i oceny stopnia bezprawności, jest zagrożenie lub naruszanie dobra prawnego w sposób niezgodny z wypracowanymi przez wiedzę i doświadczenie regułami postępowania. Konieczne jest więc uwzględnienie społecznej tolerancji dla pewnych zachowań zagrażających dobrom społecznym. Narażenie tych dóbr jest konieczne, a więc ujemnie oceniać można jedynie zbytnie narażenie, przekraczające właśnie społeczne potrzeby codzienności. Nie ma zatem wątpliwości, że pojęcie bezprawności zostaje poddane wartościowaniu ze względu na stopień dopuszczalnego niebezpieczeństwa dla dóbr chronionych przez prawo (koncentruje się na rezultacie zachowania człowieka), jak również ze względu na sposób postępowania człowieka, odpowiadający pewnym standardom postępowania $\mathrm{z}$ dobrem (skupia sią na samym zachowaniu człowieka). W razie gdy zachowanie nie przekracza dopuszczalnego rozmiaru niebezpieczeństwa lub spełnia standardy postępowania $\mathrm{z}$ dobrem - jest ono dla prawa karnego pierwotnie nieistotne.

Do tego ujęcia bezprawności nawiązuje koncepcja oparcia wszystkich kontratypów na swego rodzaju stanie wyższej konieczności - na poziomie wartościowania zachowania człowieka w zakresie normy sankcjonującej, w tym również kontratypów pozaustawowych. Kontratyp narusza normę sankcjonowaną przez atak na dobro chronione tą normą lub naruszenie przyjętych reguł postępowania $\mathrm{z}$ tym dobrem, jednak okoliczności, w jakich czyn został popełniony, usprawiedliwiają naruszenie reguł postępowania i zaatakowanie dobra, w związku z czym następuje tzw. wtórna legalizacja czynu. Usprawiedliwienie to wynika z kolizji dóbr chronionych prawnie, powodującej konieczność poświęcenia jednego z dóbr, oraz ze społecznej opłacalności, akceptowanej w danym systemie aksjologicznym, poświęcenia tego, a nie innego dobra spośród innych dóbr pozostających w kolizji. Konkludując, bezprawność wynikająca z naruszenia normy sankcjonowanej, przy braku kontratypów, jest 
warunkiem karalności. O ile okoliczność wyłączająca bezprawność może być dla prawa karnego nieistotna, o tyle kontratyp funkcjonuje w ramach prawa karnego i zawsze jest dla niego - dla karalności popełnionego czynu - istotny. Wyłącza on bezprawność zaszłego czynu, ale wyłączenie to następuje de facto w warstwie ustalania warunków karalności. Bez kontratypu czyn byłby zarówno bezprawny, jak i karalny ${ }^{38}$.

Implikacje tego wyobrażenia o roli normy wartościującej ze względu na elementy przedmiotowe postępowania człowieka i określającej bezprawność, sprzężonej z normą prawnokarną wprowadzającą karalność bezprawnego zachowania, są widoczne w licznych instytucjach i figurach prawnokarnych. Wiele z nich przejmuje orzecznictwo, prowadząc niejednokrotnie do znaczącego przeobrażenia instytucji prawnokarnych $^{39}$.

38 Zob. szerzej A. Zoll, Kontratypy a okoliczności wyłączające bezprawność czynu (w:) Okoliczności wyłączające bezprawność czynu. Materiały IV Bielańskiego Kolokwium Karnistycznego, red. J. Majewski, Toruń 2008, s. 13. Krytycznie na ten temat Z. Jędrzejewski (w:) Nauka o przestępstwie, wyłaczenie i ograniczenie odpowiedzialności karnej, red. L.K. Paprzycki, „System Prawa Karnego”, t. 4, Warszawa 2013, rozdz. $1, \S 1$.

39 Przykładem takiego postępowania judykatury jest postanowienie SN z dnia 3 stycznia 2002 r. (IV KKN 635/97, OSNKW 2002, z. 56, poz. 39) z glosą krytyczną J. Giezka (tenże, Kwestia przekroczenia obrony koniecznej. Glosa do postanowienia SN z dnia 3 stycznia 2002 r., IV KKN 635/97, „Państwo i Prawo” 2002, nr 11, s. 106-110), akcentujące zasadę względnej subsydiarności kontratypu obrony koniecznej. W orzeczeniu uznano, że „sedno oceny popełnionego w obronie koniecznej czynu nie sprowadza się do prostej subsumcji podjętego w obronie działania pod konkretne przepisy ustawy karnej, lecz tkwi w rozważeniu rodzaju, rozmiaru, wartości dóbr, jakie, za pomocą obranego środka i sposobu obrony, zostały tym działaniem świadomie naruszone; to bowiem pozwala na dokonanie dalszych rozważań $\mathrm{w}$ aspekcie oceny, czy między dobrami konfliktowymi, tj. zaatakowanym a naruszonym w wyniku obrony, zachodziła taka dysproporcja, która przesądza o przekroczeniu granic zastosowanej obrony w stosunku do niebezpieczeństwa odpieranego zamachu (...). Dopiero stwierdzenie, iż do dysproporcji [między tymi dobrami - dop. M.K.] doszło, pociąga za sobą ocenę co do bezprawności popełnionego
Ostatnim kluczowym zagadnieniem związanym $\mathrm{z}$ analizowaną tu koncepcją struktury przestępstwa jest pytanie, jaką funkcję ma pełnić zasada winy, tj. czy może ona samodzielnie decydować o ewentualnym wyłączeniu odpowiedzialności karnej z powodu niemożności uczynienia sprawcy zarzutu z popełnienia czynu bezprawnego, karalnego i karygodnego. Ponownie trzeba odwołać się do przyjętej koncepcji normy, w tym do rozróżnienia jej aspektu aksjologicznego które odgrywa podstawowe znaczenie przy ocenie bezprawności i karygodności - oraz teleologicznego, korygującego zachowania jednostek, którego znaczenie najbardziej jest widoczne przy określaniu karalności oraz zawinienia jako elementu w strukturze przestępstwa. Przyjmuje się, że nie można wymagać od człowieka podporządkowywania się normie, jeśli z powodów wystąpienia szczególnych okoliczności nie jest on w stanie dać posłuchu nakazowi lub zakazowi zawartemu w tej normie. Dlatego też mimo ustawowego zakreślenia granic wymagalności dania posłuchu normie prawnej, jak to ma miejsce przy wprowadzeniu minimalnego wieku dla przypisania winy oraz wyznaczenia granic stanu wyższej konieczności - możliwość dania autorytetu danej normie musi być ustalana w konkretnych wypadkach od tego niezależnie, na podstawie art. $1 \$ 3$ k.k.

Wydaje się, że autorzy pozostający pod wpływem tego kierunku wskazują, iż między modelem wyprowadzania reguł $\mathrm{z}$ indywidualnych spraw a modelem podporządkowywania oceny faktów stworzonym uprzednio regułom ogólnych warunków odpowiedzialności karnej przewaga tego drugiego wiąże się z wypełnianiem funkcji gwarancyjnej. Uważają, że dopiero wówczas te zasady trzymają w ryzach dowolność wykładni znamion, a nawet przeciwdziałają spłaszczaniu procesu badania podstaw odpowiedzialności karnej do rozumowania wyłącznie w obrębie znamion. Niekiedy to nie zapalczywości teoretycz-

w obronie czynu, a dalej konieczność jego zakwalifikowania z odpowiednich przepisów ustawy karnej. Jakkolwiek więc popełniony w obronie koniecznej czyn musi - co oczywiste - realizować znamiona typu czynu zabronionego, to jego analiza przebiega na innej nieco płaszczyźnie, zasadniczo bowiem koncentruje się na ocenie dobra, jakie tym czynem zostało naruszone". 
nej, lecz przekonaniu o konieczności wymuszenia na praktyce określonego etapu rozumowania, pomijanego $\mathrm{w}$ procesie badania znamion, należy w mojej ocenie przypisywać dekretowanie na poziomie ustawowym określonych rozwiązań, jak ma to miejsce w przypadku rozbicia strony podmiotowej i winy. Wartościując zatem tę metodę ze względu na wpływ na postępowanie dowodowe w obrębie procesu karnego, należy więc wskazać, że jest ona relatywnie złożona, czynu, ujęciu podstaw przestępnego współdziałania i wielu innych ${ }^{40}$. $Z$ tego też wynika sceptyczna wypowiedź Ryszarda Dębskiego, który podnosi, że omawiany sposób prowadzenia badań nad prawem karnym „zamiast ułatwienia badań podstawowych konstrukcji nauki o przestępstwie może prowadzić do narastania kolejnych sporów i wątpliwości oraz generowania polemik"41 , choć sądzę, że jest to krytyka w tak jednoznacznym ujęciu całkiem niesprawiedliwa.

\section{Między modelem wyprowadzania reguł} $z$ indywidualnych spraw a modelem podporządkowywania oceny faktów stworzonym uprzednio regułom ogólnych warunków odpowiedzialności karnej przewaga tego drugiego wiąże się $\mathrm{z}$ wypełnianiem funkcji gwarancyjnej.

wymaga weryfikowania w rozstrzyganiu niemal każdego przypadku - przynajmniej niektórych warstw struktury przestępstwa - dla oceny wypełnienia znamion czynu zabronionego i w założeniu zmusza do większej drobiazgowości w realnym ustalaniu obiektywnych podstaw ogólnych do odpowiedzialności karnej danej jednostki.

Krytyka przedstawionej metody nawiązuje jednak do tych samych wartości, które w ocenie propagatorów powinny skłaniać ku niej praktykę wymiaru sprawiedliwości. W nieuzasadnionym rozbudowywaniu zakresu części ogólnej w stosunku do części szczególnej dopatruje się procesu „dekonkretyzacji” i w konsekwencji często zmiany granic odpowiedzialności karnej. Nie sposób pominąć tego, że niemal każda kontrowersja dotycząca ogólnych zagadnień związanych z dekodowanymi z przepisów prawa karnego strukturami normatywnymi odbija się na propozycjach metodologicznych rozwiązywania szczegółowych problemów prawnokarnych, tak jak w przypadku okoliczności kontratypowych, redukcji wielości ocen, tożsamości
Zarzuca się także, że przy wyjmowaniu przed nawias poszczególnych typów części ogólnej, poddanej autonomicznej i prosystemowej analizie dogmatycznej, dochodzi często do odrywania odpowiedzialności karnej od rzeczywistości empirycznej i społecznej, ale także do zerwania z normatywnym punktem odniesienia, jakim są szczegółowe zespoły znamion ustawowych. W konsekwencji przesunięcia w obrębie danej kategorii części ogólnej mogą prowadzić do zmian zakresów zakazów, w tym do arbitralnego rozszerzenia lub redukcji odpowiedzialności karnej, a systematyce przestępstwa mogą odebrać funkcję gwarancyjną ${ }^{42}$.

40 Przykładowo zob. M. Bielski, Koncepcja kontratypów jako okoliczności wyłączających karalność, „CzPKiNP” 2010, z. 2, s. 25 i n.; W. Wróbel, Konstrukcja kontratypu..., s. 369.

41 R. Dębski, Jeszcze o normie, s. 116-117; zob. również okoliczności przywołania tej wypowiedzi w sposobie omówienia normy sankcjonującej i sankcjonowanej w prawie karnym przez L. Gardockiego (Prawo karne..., s. 34-35).

42 Z. Jędrzejewski, Bezprawność..., s. 82-83. 


\section{Metoda kontekstowych modeli argumentacyjnych}

W tym przypadku trudno mówić o utrwalonej teorii dogmatyki prawa karnego. Mamy do czynienia bowiem z podejściem wielonurtowym i poszukującym przede wszystkim adekwatności materialnej wypracowywanych rozwiązań, w niej dostrzegającym podstawę do wykazywania wiarygodności rozwiązań, nie zaś w samej metodzie formalno-dogmatycznej. Tak konstruowany warsztat pracy z materiałem prawnym obejmuje zarówno mieszaną metodę dogmatyczną odwołującą się do narzędzi wypracowanych w powyżej zreferowanych podejściach dogmatycznych, jak też test merytorycznej zasadności względem natury relacji odpowiedzialności karnej w ogóle i w danych wypadkach. Jest to zatem podejście pragmatyczne $\mathrm{w}$ takim rozumieniu, że nie przyznaje ono priorytetu spójności systemowej i klarowności, czy też zgodności z precyzyjnie opisaną siatką pojęciową, ale za wiodące uznaje użycie wszystkich relewantnych, dostępnych w dorobku naukowym i orzeczniczym narzędzi dla uzyskania adekwatnej reakcji karnej w konkretnym stanie faktycznym. Jednocześnie w koncepcji tej nie lekceważy się zagadnienia materialnej dostępności norm prawnokarnych dla uczestników życia społecznego, koniecznej dla zapewnienia właściwej dla zasady demokratycznego państwa prawa realności założenia znajomości reguł odpowiedzialności karnej i zakazów karnych, jak i społecznej akceptowalności funkcjonowania systemu wymiaru sprawiedliwości w sprawach karnych ${ }^{43}$.

W świetle powyższego łatwo zauważyć, że zwolennicy niniejszego podejścia dystansują się wobec istoty sporu co do konstrukcji bezprawności czy samej systematyki przestępności i przyjmują w zakresie możliwym do pogodzenia zarówno założenie o konieczności zachowania spójności rozstrzygnięć prawnokarnych z ogólnymi wypowiedziami dotyczącymi założeń ustroju i podstawowych wartości poddanych ochronie, która to ochrona powinna być w każdym z układów normatywnych i faktycznych maksymalizowana, jak i elastyczność konstrukcji zakazów karnych, by posiadały one zdolność do odpowiadania na potrzebę harmonizacji ogólnego kontekstu aksjologicznego

43 K. Szczucki, Wykładnia prokonstytucyjna..., s. 59-60. wypowiedzianego w konstytucyjnym ujęciu systematyki dóbr chronionych. W tej metodzie odnajdziemy zarówno argumenty za subsydiarnością prawa karnego, jak i pozytywnie ujmowaną koniecznością istnienia prawa karnego, w zależności od rodzaju dobra i potrzeby jego ochrony. Tak dokonana charakterystyka mogłaby stanowić dodatkowe wytłumaczenie dla klasycznej metody dogmatycznej. Jednakże należy dołączyć do niej i drugi wymiar, tym razem przemawiający za wartością systemowych struktur normatywnych w warsztacie dogmatycznym prawa karnego. Omawiane podejście bardzo mocno akcentuje wyodrębnienie normy sankcjonowanej wyprowadzanej oczywiście w kontekście typu czynu zabronionego, a dokładniej z treści dóbr chronionych i zasad postępowania z nimi, ale nie redukowanej do treści zakazu karnego, i normy sankcjonowanej, w której zostaną ulokowane ścisłe znamiona typu czynu zabronionego. Rozróżnienie to ma znaczenie warsztatowo-interpretacyjne, nie zaś systemowo-dogmatyczne. Przyjmuje się, że tylko takie rozróżnienie pozwoli na równoczesne użycie dwóch modeli interpretacyjnych - wykładni systemowej, kontekstowej, umożliwiającej odczytywanie prawa karnego w systemie rozstrzygnięć wzorców konstytucyjnych, w szczególności definiujących system i hierarchię dóbr prawnych poddanych procedurze ochronnej w systemie prawa, a także wykładni ścisłej, głównie językowo-logicznej, ograniczających ekspansję znaczeniową znamion typu czynu zabronionego niezwiązaną z wykładnią w zgodzie z konstytucją. Dotyczy to przede wszystkim sposobu, w jaki system wartości konstytucyjnych, poddanych porządkowi wyznaczonemu przez zasadę godności i dobra wspólnego, wpływa na system dóbr chronionych prawem karnych oraz sposób obchodzenia się z tymi dobrami w obrocie prawnym. Nie pozostaje zatem bez wpływu również na sposób rekonstrukcji zasad odpowiedzialności karnej, zarówno co do kształtu przypisywalności sprawstwa, jak i jego zakresu. Nie dlatego, że rozwiązania konstytucyjne wymuszają określone konstrukcje, takie jak obiektywne przypisanie skutku czy skutkowość podżegania, ale z tego powodu, że kształt tych rozwiązań w lepszym niż inne stopniu oddaje konstytucyjne zapatrywania na sens odpowiedzialności karnej. Omówione podejście pozwala również na zaakceptowanie takiego rozwią- 
zania, że korekta wyniku stosowania podstawowych kategorii odpowiedzialności karnej może przyjść niejako z zewnątrz systemu dogmatycznego, co wymaga, by konsekwentnie dogmatykę prawnokarną uczynić otwartą na elementy spoza systemu formalno-logicznego rozumowania.

Pierwszym wiodącym założeniem kontekstowej teorii dogmatyki prawa karnego jest przykładanie szczególnej wagi do relacyjnego charakteru odpowiedzialności karnej. W tej oto myśli zakotwicza się podstawowe założenie, jakim jest poszukiwanie takiego sposobu ukształtowania zasad odpowiedzialności karnej - w ogóle i w danym przypadku - który pozwoli na rzeczywiste zdanie rachunku ze swego postępowania względem innych podmiotów, a mianowicie wspólnoty społecznej i pokrzywdzonego. Komunikacja między członkami wspólnoty normatywnej, jaką jest społeczeństwo ujęte w ramy porządku prawnego, następuje za pomocą rozstrzygnięć optymalizujących ochronę dóbr prawnych uczestniczących w obrocie. Innymi słowy mówiąc, podejście to zakłada, że odpowiedzialność karna będzie zrozumiała według ogólnosystemowych kryteriów porządku konstytucyjnego - nie chodzi tu wyłącznie o spełnianie zasad odpowiedzialności karnej, takiej jak nullum crimen sine lege, ale wiarygodność w świetle rozstrzygnięć konstytucyjnych odpowiedzialności karnej jednostki, zwłaszcza w danym przypadku.

Należy wziąć pod uwagę, że prawo karne jest częścią szerszego systemu prawnego, niezależnie od tego, czy wypowiemy to teoretycznie przez konstrukcję ogólnej bezprawności, czy bezprawności karnej redukowanej komponentem „obcej bezprawności”. Inaczej dochodzi do otwarcia prawa karnego na arbitralność ustawodawcy co do możliwości zaprojektowania norm prawnokarnych, a także na rozchwianie sposobu jego stosowania przez organy wymiaru sprawiedliwości w podobnych przypadkach ${ }^{44}$. Tylko bowiem przez odwołanie się do wzorców konstytucyjnych stanowiących samodzielną przesłankę kontroli zgodności rozstrzygnięć ustawowych, a także przez uwzględnienie konkurencji norm konstytucyjnych chroniących prawa jednostki i wolności obywatelskie oraz konieczność ich kompromisowego komponowania można kreować

44 Tamże, s. 102-104. docelową wypowiedź normatywną dotyczącą podstaw odpowiedzialności karnej i treści decyzji kryminalizacyjnej w sposób odpowiednio komponujący się w system prawny danego państwa oraz kulturę stosowania prawa jako całości. Daje to zewnętrzny względem prawa karnego normatywny punkt odniesienia dla weryfikacji krytycznej stosowania tej regulacji przez organy wymiaru sprawiedliwości, które są konfrontowane nie tylko z odmienną możliwością wykładni znamion ustawowych, ale i z koniecznością wyboru takiej wykładni, która w największym stopniu uwzględni skutki harmonizowania kontekstu konstytucyjnego (wykładni w zgodzie z konstytucją). Od tego wszak zależy zwiększenie rzeczywistego wypełnienia przez prawo karne funkcji ochronnej, zaprojektowanej przez zgodność z centralnym elementem systemu prawnego, jakim jest zespół zasad ustrojowych i norm programujących wartości, wokół których zorganizowano system prawny.

Z powyższego wywieść należy konkretną składową warsztatu dogmatycznego. Rację ma bowiem Jacek Giezek, który wykazuje, że kolizja dóbr stanowi podstawę wszystkich typów przestępstw ${ }^{45}$, przy czym wypowiedź ta nabiera pełnego sensu nie tyle w kontekście analizy dogmatycznej zespołu znamion lub włączaniu dozwolonego ryzyka do struktury przestępstwa jako przestrzeni, w której rozmiar i rodzaj pozytywnego, społecznie aprobowanego celu i prawdopodobieństwo jego osiągnięcia przeważają nad rodzajem i rozmiarem negatywnego skutku i prawdopodobieństwem jego wystąpienia, ile wobec konieczności analizy konkretnego typu oraz zespołu chronionych i ograniczanych przez zakaz dóbr (wartości konstytucyjnych) w kontekście systemu wzorców konstytucyjnych i innych aksjologicznych punktów odniesień, na które konstytucja otwiera obowiązujący porządek prawny. Istotą tego sposobu rozumowania jest osiągnięcie - w ramach wyznaczanych warstwą językową przepisu prawnokarnego - systemu zasad indywidualnej odpowiedzialności karnej i przypisania sprawstwa, jak również takiego odczytania typu przestępstwa, które maksymalizuje ochronę wypowiedzianych w konstytucji wartości

45 J. Giezek, Przyczynowość oraz przypisanie skutku w prawie karnym, „Acta Universitatis Wratislaviensis” 1994, nr 1608, Prawo CCXXIX, s. 162. 
(w szczególności podstaw aksjologicznych systemu normatywnego, wolności i praw człowieka i obywatela, zasad ustrojowych) pozostających w danym wypadku w kolizji ${ }^{46}$. Tego rodzaju postępowanie może przybierać dwie nie zawsze możliwe do precyzyjnego rozróżnienia formy: (1) wykładni ustaw w zgodzie z konstytucją, która oznacza - w sytuacji gdy istnieje kilka sposobów dekodowania normy - wyeliminowanie tego, który prowadziłby do ustalenia treści normy sprzecznej z normami konstytucji; (2) tzw. wykładni zorientowanej na konstytucję, a więc taki zabieg interpretacyjny, który prowadzi do jak największego stopnia realizacji wartości konstytucyjnych.

Przyjmuje się, że wykładnia ustaw w zgodzie z konstytucją jest konsekwencją nadrzędności konstytucji i domniemania konstytucyjności ustaw. Wykładnia zorientowana na konstytucję zakłada kształtowanie się danej gałęzi prawa w sposób możliwie w pełni osadzony w aksjologii wypowiedzianej przez ustrojodawcę ${ }^{47}$. W ramach badania zgodności przepisów karnych z konstytucją należy uwzględnić całą treść wyrażonych w tych przepisach norm, czyli także opis czynu zabronionego oraz rodzaj i surowość sankcji. Badanie decyzji kryminalizacyjnej zakłada zatem analizę prawidłowości wprowadzenia karalności, ukształtowania typu i możliwości wykładni zorientowanej na konstytucję, jak też surowość represji karnej. Analiza ta wymaga ${ }^{48}$ : (1) określenia przez pryzmat norm konstytucyjnych dóbr prawnych, które uzasadniają ingerencję prawnokarną w wolność jednostki; (2) ustalenia wzorców kontroli zgodności z konstytucją przepisów prawa karnego, jak również oceny rodzaju wypowiedzi konstytucyjnej i wynikającego z niej stopnia związania ustawodawcy wypowiedzią ustrojodawcy (np. normą programową, normą gwarancyjną lub zakazem kon-

46 P. Kardas, Rozproszona kontrola konstytucyjności prawa w orzecznictwie Izby Karnej Sądu Najwyższego oraz sądów powszechnych jako wyraz sędziowskiego konstytucyjnego posłuszeństwa, „e-CzPKiNP” 2019, nr 4, wydanie internetowe.

47 Szerzej zob. P. Tuleja, Stosowanie Konstytucji RP w świetle zasady jej nadrzędności (wybrane problemy), Kraków 2003, s. $210 \mathrm{in}$.

48 Zob. zwłaszcza wyrok TK z dnia 30 października 2006 r., P 10/06, OTK-A 2006, nr 9, poz. 128. stytucyjnym $^{49}$ ), wreszcie - oceny relacji, w jakiej te wzorce pozostają względem siebie; (3) uwzględnienia kolizji wartości konstytucyjnych i preferowanego przez ustrojodawcę sposobu jej rozwiązania (decyzja interpretacyjna w odniesieniu do norm konstytucji) dla oceny decyzji kryminalizacyjnej i wykładni znamion konkretnego typu przestępstwa; a w końcu również (4) oceny zasadności systemu represji karnej ${ }^{50}$.

Drugą istotną cechą omawianego kierunku warsztatowego jest akcentowanie wtórnego normatywizmu prawa karnego względem norm przewidujących odpowiedzialność etyczną i relacji w niej zachodzących. W poprzednim punkcie dostępność społeczna prawa karnego wyprowadzana była z materialnej treści rozstrzygnięć i ich zgodności z zespołem wartości chronionych przez porządek prawny według systematyki i założeń konstytucji - podejmowanych zarówno na poziomie ustawodawczym, jak i w pożądanej praktyce stosowania prawa karnego. W tym natomiast momencie chodzi o dostępność struktur odpowiedzialności karnej w znaczeniu, w jakim rozstrzygają one o tym, kiedy dana osoba ma ponosić odpowiedzialność karną, a kiedy może się z niej ekskulpować lub skutecznie usprawiedliwić swoje postępowanie. Dla wyjaśnienia tego poglądu należy w pierwszej kolejności zaznaczyć, że zakres akceptowalnej odpowiedzialności karnej, wyrażanej w konkretnych instytucjach przypisywalności sprawstwa, jest pewnego rodzaju dorobkiem kultury rozwoju prawa. Nie jest jednak tak, że ustawodawca

49 Zob. P. Tuleja, Stosowanie Konstytucji RP..., s. 268-269; K. Działocha, Hierarchia norm konstytucyjnych $i$ jej rola w rozstrzyganiu kolizji norm (w:) Charakter i struktura norm konstytucyjnych, red. J. Trzciński, Warszawa 1997, s. 78 i n.

50 Zaproponowany porządek rozumowania jest aktualny w przypadku wszystkich omówionych wcześniej argumentacji zapewniających harmonizowanie kontekstu Konstytucji RP w prawie karnym, z tym jednak zastrzeżeniem, że w zależności od rodzaju argumentacji odmienny może okazać się kierunek rozumowania wyznaczony np. przez system domniemań zgodności z Konstytucją RP (uzasadnienie niezgodności przepisu z Konstytucją RP) lub zasadę stosunkowości z art. 31 ust. 3 Konstytucji RP (uzasadnienie decyzji kryminalizacji lub penalizacji w procesie legislacyjnym - zob. M. Królikowski, Ogólna ocena projektu nowelizacji Kodeksu karnego i jego zgodności z Konstytucją, „Zeszyty Prawnicze BAS” 2007, nr 3, s. 89 i n.). 
ma pełną swobodę w kreowaniu podstaw normatywnych takiej odpowiedzialności prawnej, a przynajmniej korzystając ze swojej swobody, powinien uwzględniać naturę relacji, w jakich ponosimy odpowiedzialność etyczną względem innych osób. Na tę prawidłowość zwraca uwagę przesuwanie się subiektywnych granic odpowiedzialności karnej ${ }^{51}$ czy też dość wymuszona recepcja odpowiedzialności podmiotów zbiorowych w europejskich systemach prawa karnego. nie, o tyle ryzyko w nim wyrażone wiąże się z dużą podatnością tej konkretnej argumentacji na populizm penalny i komunikację uproszczoną, podkręcającą emocje związane z potrzebą ukarania, jak to było niedawno w przypadku zmian okresu przedawnienia lub systemu kar i środków zabezpieczających w nowelizacjach Kodeksu karnego z lat 2013-2017. Niewątpliwie otwiera to prawo karne na kontekst stron procesu karnego w celu wywodzenia adekwat-

\section{Rozstrzyganie każdego przypadku musi zakładać} test materialnej wiarygodności związany $z$ oceną odpowiedniego zestawienia norm optymalizujących ochronę określonych dóbr w systemie prawa, jak i test systemowej wiarygodności odwołujący się do badania aplikacji ogólnych zasad odpowiedzialności karnej.

Zatrzymując się jednak nad istotą owego w tórnego normatywizmu, należy podkreślić, że wyraża się w nim zależność między dostępnością reguł odpowiedzialności karnej a ich zbieżnością z funkcjonującymi w społeczeństwie kryteriami odpowiedzialności etycznej. Chodzi o to, by zakres wywodzonej z norm prawa karnego odpowiedzialności nie prowadził do wyników absurdalnych z punktu zinternalizowanych $\mathrm{w}$ społeczeństwie reguł rozliczenia się z danego postępowania. Jest to zależność, jaka przebiega przez ogólne zasady odpowiedzialności karnej (np. relacja między zamiarem ewentualnym a zasadą podwójnego skutku), jak i w przypadku zakresu materialnoprawnej podstawy odpowiedzialności karnej w danym wypadku. O ile wartość tego podejścia wiąże się z poszukiwaniem przez prawo karne autorytetu ze względu na zgodność $\mathrm{z}$ wewnętrznymi dla społeczeństwa procedurami wywodzenia odpowiedzialności jednostki za swoje postępowa-

51 J. Kochanowski, Subiektywne i obiektywne granice..., passim. nego rozstrzygnięcia - dla potrzeby ukarania, zadośćuczynienia społecznemu poczuciu sprawiedliwości lub naprawienia szkody.

Po trzecie, w omawianym kierunku dostrzeżemy uwzględnianie funkcjonalności praktycznej narzędzi dogmatycznych wywodzonych zarówno $\mathrm{z}$ teorii struktur normatywnych, jak i z klasycznej teorii analizy dogmatycznej. Ponadto metoda ta w największym stopniu z omówionych wyżej sposobów posługiwania się prawem karnym pozwala na ustalanie związku poszczególnych norm prawnych z ich teleologiczną podstawą, zarówno względem norm ogólnych, jak i wyrażonych w konstrukcji zakazów karnych. Zrywając z gorsetem formalizmu myślenia systemowego, ale nie odrzucając samej metody, pozwala na twórcze kształtowanie prawa. Na tę metodę, jak mniemam, zwracają również uwagę niemieccy autorzy, którzy podnoszą wartość metodyki właściwej dla tzw. otwartego systemu porządkowania materiału prawnego otwartego na zewnątrz, czyli na oceny poza strukturą zakazów karnych, i otwartego do wewnątrz, a więc na 
metody używane w pracy dogmatycznej z materiałem prawnym w obszarze prawa karnego ${ }^{52}$. Jest to zatem w ostatecznym rozrachunku metoda zakładająca, że w rozstrzyganiu konkretnych przypadków konieczne jest również odwołanie się do sądów i idei wartościujących cały porządek normatywny. Przy czym to nie w spójności tych idei, czyli w formalnej koherentności systemu prawa, lecz w samej systemowości porządku prawnego widzi się tu istotny potencjał warsztatowy i dowodowy. Polega on na tym, że rozstrzyganie każdego przypadku musi zakładać test materialnej wiarygodności związany z oceną odpowiedniego zestawienia norm optymalizujących ochronę określonych dóbr w systemie prawa, jak i test systemowej wiarygodności odwołujący się do badania aplikacji ogólnych zasad odpowiedzialności karnej w danym przypadku. Wyraża się pogląd, że prawo karne powinno zachować zdolność do odpowiedzi na akceptowaną społecznie potrzebę odpowiedzialności karnej osób występujących we wspomnianych rolach sprawczych lub naruszających szczególnego rodzaju zakazy i różne powody kryminalizacji, pod warunkiem ich zgodności z wzorcami oceny konstytucyjnej.

W omawianej wersji warsztatu dogmatycznego rozstrzygające staną się nie tyle konkretna struktura przestępstwa albo koncepcja znamion typu czynu zabronionego, ile otwartość zaproponowanych koncepcji dogmatycznych na kilka wiodących, opisanych powyżej, założeń merytorycznych. Mianowicie w każdym akcie stosowania prawa karnego domagać się należy dokonania wykładni w zgodzie z konstytucją w zakresie podstaw odpowiedzialności karnej oraz dóbr chronionych przez typ czynu zabronionego, uwzględnienia przypisania sprawstwa na płaszczyźnie obiektywnej, obejmującej reguły postępowania z dobrem, oraz subiektywnej, obejmującej zarówno znamiona strony podmiotowej, jak i zarzucalność, a także ścisłej wykładni znamion najpełniej oddających ochronę wartości konstytucyjnych, zarówno w wyniku funkcji legalizującej, jak i nakazującej kryminalizację. Można jeszcze inaczej powiedzieć, że istotą tej metody jest wprowadzenie do modelu wnioskowania narzędzi korygujących wyniki analizy dogmatycznej ze względów systemowych i potrzeby

52 Z. Jędrzejewski, Bezprawność..., s. 28-29. realnej dostępności treści norm prawnokarnych. W tym też to rozumieniu wskazane podejście najpełniej otwiera się na potrzeby związane ze spełnieniem przez rozwiązania dogmatyczne określonej roli dowodowej, ale i nie jest w stanie samodzielnie, bez odwołania się do rozwiązań warsztatowych wypracowanych przez omówione wcześniej metody pracy z tekstem prawnym, spełnić dostatecznej roli gwarancyjnej.

\section{Preferencja wyboru}

Wiele lat temu, kiedy próbowałem dociekać, dlaczego do ostatniej dekady XX wieku w kanonie polskiej myśli prawniczej, w tym oczywiście karnistycznej, dominowały pozycje pozytywizmu prawnego, ktoś mądry wytłumaczył mi, że był to jedyny sposób obrony przed nadużyciami wynikającymi z woli politycznej. Wtedy, kiedy świadomie prawo karne skoncentrowano wokół zespołu znamion i dopuszczano swobodę w postępowaniu z zasad przypisania odpowiedzialności, sądowa racjonalizacja interesów ścigania wiązała się z interpretacją literalną zakresów zakazów. O ile broniło to poczucia niezawisłości, to warunki, w jakich następowało, zwłaszcza sposób typizacji i towarzysząca temu treść doktryny, nie czyniły z tej metody bynajmniej brzytwy skutecznie wykrawającej zachowania nieprzestępne. Nie bez powodu zwracano uwagę, że w przypadku orzekania na podstawie dekretu o stanie wojennym wystarczyłoby powołanie się na teorię winy w rozumieniu błędu co do prawa, by ekskulpować opozycjonistów ${ }^{53}$.

Kiedy obserwowałem, jak po powszechnym otwarciu polskiego świata prawniczego - zwłaszcza po wejściu w życie Konstytucji $\mathrm{RP}^{54}$, a potem akcesji do UE - na wykładnię systemową podstawową troską było określenie granic swobody interpretacyjnej oraz możliwości twórczej wykładni w orzecznictwie sądów powszechnych, Sądu Najwyższego i Trybunału Konstytucyjnego, dostrzegłem ucieranie się poglądu, że uprawnienie takie nie powinno być przypisane do

53 J. Kochanowski, T. de Virion, Zagadnienie świadomości bezprawności a odpowiedzialność $z$ dekretu o stanie wojennym z 12 XII 1981 r., „Państwo i Prawo” 1983, nr 3, s. 96-100.

54 Konstytucja Rzeczypospolitej Polskiej z dnia 2 kwietnia 1997 r. (Dz.U. nr 78, poz. 483 z późn. zm.). 
sądów powszechnych, zwłaszcza niższych instancji. Wynikało to, jak mniemam, z troski o zapewnienie jednolitości orzeczniczej, uzyskiwania przez system zdolności do zinternalizowania metod sięgających do nowych modeli argumentacyjnych oraz upoważnienia do twórczego odniesienia się do klasycznych wyników interpretacji karnistycznej ${ }^{55}$. Temu przecież towarzyszył również spór między Sądem Najwyższym a Trybunałem Konstytucyjnym dotyczący uprawnienia do wydawania wyroków interpretacyjnych ${ }^{56}$.

Obecnie, kiedy wobec upadku utrwalonego modelu konstytucyjnej ochrony wolności i praw człowieka i obywatela formułowane są radykalnie odmienne propozycje rozproszonej kontroli konstytucyjnej w orzecznictwie sądów powszechnych, gdy te przecież w sprawach karnych w niezwykle ograniczonym stopniu spełniają funkcję dyscyplinującą i weryfikującą pozycję oskarżyciela publicznego, pozostaje rzeczywiście pytanie, jaka metoda pracy z materiałem normatywnym w sądach karnych daje nadzieję na realną ochronę jednostki przed zachłannością zakazu karnego i arbitralnością autora skargi. Jestem przekonany, że bez uświadomienia sobie znaczenia klasycznej metody interpretacji karnistycznej w działalności orzeczniczej oraz zdystansowania się od niej - nadzieja na skuteczną kontrolę sądową w procesie karnym jest płonna. Pozostałe metody dogmatyczne, choć dają na to większą szansę, wymagają rzeczywistej woli i determinacji w realizacji gwarancji wolności i praw jednostki, innymi słowy - trzymania prawa karnego w ryzach na każdym etapie jego postępowania. Z pewnością same z siebie nie są pewnikiem większej gwarancyjności w działaniu sądów karnych. To przecież dalej wciąż jeszcze początek, a każdy kolejny - będzie jak jakiś ciąg dalszy.

55 W. Wróbel, Prawotwórcze tendencje w orzecznictwie Sądu Najwyższego w sprawach karnych (w:) W kręgu teorii i praktyki prawa karnego. Księga poświęcona pamięci Profesora Andrzeja Wąska, red. L. Leszczyński, E. Skrętowicz, Z. Hołda, Lublin 2005.

56 A. Mączyński, Bezpośrednie stosowanie Konstytucji przez $s a d y$, „Państwo i Prawo” 2000, nr 5, s. 3-14; S. Wronkowska, W sprawie bezpośredniego stosowania Konstytucji, „Państwo i Prawo” 2001, nr 9, s. 3-23.

\section{Bibliografia}

Andrejew I., Polskie prawo karne w zarysie, Warszawa 1976.

Bielski M., Koncepcja kontratypów jako okoliczności wyłączających karalność, „Czasopismo Prawa Karnego i Nauk Penalnych" 2010, z. 2, s. 25-50.

Budyn-Kulik M., Umyślność w prawie karnym i psychologii. Teoria i praktyka sq̨dowa, Warszawa 2015.

Dębski R., Jeszcze o normie prawnokarnej (w:) Nauki penalne wobec szybkich przemian socjokulturowych. Księga jubileuszowa Profesora Mariana Filara, t. 1, Toruń 2012.

Działocha K., Hierarchia norm konstytucyjnych i jej rola $w$ rozstrzyganiu kolizji norm (w:) Charakter i struktura norm konstytucyjnych, red. J. Trzciński, Warszawa 1997.

Gardocki L., Pozaustawowe źródła znaczenia przepisu karnego (w:) W kręgu teorii i praktyki prawa karnego. Księga poświęcona pamięci profesora Andrzeja Wąska, Lublin 2005.

Gardocki L., Prawo karne, Warszawa 2015.

Giezek J., Kwestia przekroczenia obrony koniecznej. Glosa do postanowienia SN z dnia 3 stycznia 2002 r., IV KKN 635/97, „Państwo i Prawo” 2002, nr 11, s. 106-110.

Giezek J., Metoda prawa karnego. O budowaniu „karnistycznych” teorii naukowych oraz ich wpływie na odpowiedzialność karną, „Wrocławskie Studia Erazmiańskie” 2014, t. 8, s. 29-55.

Giezek J., O możliwości naukowego uzasadnienia zmiany modelu odpowiedzialności karnej, „Państwo i Prawo” 2017, nr 2, s. 3-19.

Giezek J., Przyczynowość oraz przypisanie skutku w prawie karnym, „Acta Universitatis Wratislaviensis” 1994, nr 1608, Prawo CCXXIX.

Jędrzejewski Z., Bezprawność jako element przestępności czynu, Warszawa 2009.

Jędrzejewski Z. (w:) Nauka o przestępstwie, wyłączenie i ograniczenie odpowiedzialności karnej, red. L.K. Paprzycki, „System Prawa Karnego”, t. 4, Warszawa 2013, rozdz. 1, § 1, s. 30-156. Jędrzejewski Z., Zgoda dysponenta dobrem a struktura przestępstwa, „Prokuratura i Prawo” 2008, nr 5, s. 36-44.

Kaczmarek T., O bezprawności i strukturze przestępstwa, „Państwo i Prawo" 2010, nr 7, s. 88-98.

Kardas P., O relacjach między struktura przestępstwa a dekodowanymi z przepisów prawa karnego strukturami normatywnymi, „Czasopismo Prawa Karnego i Nauk Penalnych” 2012, z. 4, s. 5-63.

Kardas P., Rozproszona kontrola konstytucyjności prawa w orzecznictwie Izby Karnej Sądu Najwyższego oraz sądów powszechnych jako wyraz sędziowskiego konstytucyjnego posłuszeństwa, „e-Czasopismo Prawa Karnego i Nauk Penalnych” 2019, nr 4, wydanie internetowe, s. 1-45. 
Kardas P., Teoretyczne podstawy odpowiedzialności karnej za przestępcze współdziałanie, Kraków 2001.

Kardas P., Zbieg przepisów ustawy w prawie karnym, Warszawa 2011.

Kochanowski J., de Virion T., Zagadnienie świadomości bezprawności a odpowiedzialność z dekretu o stanie wojennym $z 12$ XII 1981 r., „Państwo i Prawo” 1983, nr 3, s. 96-100.

Kochanowski J., O zbędności teorii przyczynowości w prawie karnym, „Państwo i Prawo” 1967, nr 11, s. 780-790.

Kochanowski J., Subiektywne i obiektywne granice odpowiedzialności karnej, Warszawa 1982.

Królikowski M., Ogólna ocena projektu nowelizacji Kodeksu karnego i jego zgodności z Konstytucją, „Zeszyty Prawnicze BAS” 2007, nr 3, s. 89-111.

Królikowski M., Okoliczności wyłączające bezprawność jako konstrukcja sprawiedliwości korygującej, „Czasopismo Prawa Karnego i Nauk Penalnych” 2010, z. 2, s. 5-24.

Majewski J., Czy idea tak zwanej wtórnej legalności się broni, „Nowa Kodyfikacja Prawa Karnego”, t. XLIII, Księga jubileuszowa Profesora Tomasza Kaczmarka, red. J. Giezek, D. Gruszecka, T. Kalisz, Wrocław 2017, s. 401-420.

Majewski J., O schemacie budowy norm prawa karnego w piśmiennictwie karnistycznym (w:) Źródła prawa karnego, red. T. Bojarski, „System Prawa Karnego”, t. 2, Warszawa 2011.

Majewski J., Prawnokarne przypisanie skutku przy zaniechaniu, Kraków 1997.

Majewski J., „Ten sam czyn” jako jedna z przesłanek kumulatywnej kwalifikacji (w:) Zbieg przepisów oraz zbieg przestępstw w polskim prawie karnym, red. tegoż, Toruń 2006.

Małecki M., Między bezprawnością, karalnością i winą (na marginesie artykułu prof. Zbigniewa Jędrzejewskiego), „Czasopismo Prawa Karnego i Nauk Penalnych” 2017, z. 3, s. 76-94.

Mączyński A., Bezpośrednie stosowanie Konstytucji przez sądy, „Państwo i Prawo” 2000, nr 5, s. 3-14.

Pohl Ł., Prawo karne. Wykład części ogólnej, wyd. 1, Warszawa 2010.

Roxin C., Strafrecht. Allgemeiner Teil, Bd. I, Grundlagen. Der Aufbau der Verbrechenslehre, München 2006, s. 211-214.

Spotowski A., Karalność w razie braku zagrożenia dobra prawnego, „Państwo i Prawo” 1988, nr 7, s. 75-81.

Stelmach J., Brożek B., Metody prawnicze. Logika - analiza argumentacja - hermeneutyka, Kraków 2004.
Szczucki K., Rola zgody w strukturze przestępstwa na przykładzie przestępstwa zgwałcenia, „Czasopismo Prawa Karnego i Nauk Penalnych” 2011, z. 1, s. 31-58.

Szczucki K., Wykładnia prokonstytucyjna prawa karnego, Warszawa 2015.

Tarnawski M., Zagadnienia jedności i wielości przestępstw, Poznań 1977.

Tuleja P., Stosowanie Konstytucji RP w świetle zasady jej nadrzędności (wybrane problemy), Kraków 2003.

Wolter W., Klauzule normatywne w przepisach karnych, „Krakowskie Studia Prawnicze" 1969, nr 2, s. 5-37.

Wronkowska S., W sprawie bezpośredniego stosowania Konstytucji, „Państwo i Prawo” 2001, nr 9, s. 3-23.

Wróbel W., Konstrukcja kontratypu jako sposób uadekwatnienia treści normy sankcjonowanej i sankcjonującej w procesie wykładni prawa karnego (w:) W poszukiwaniu dobra wspólnego. Ksiega jubileuszowa Profesora Macieja Zielińskiego, red. A. Choduń, S. Czepita, Szczecin 2010.

Wróbel W., Prawotwórcze tendencje w orzecznictwie Sądu Najwyższego w sprawach karnych (w:) W kregu teorii i praktyki prawa karnego. Księga poświęcona pamięci Profesora Andrzeja Wąska, red. L. Leszczyński, E. Skrętowicz, Z. Hołda, Lublin 2005, s. 383-397.

Wróbel W., Relacyjne i wartościujące ujęcie bezprawności w prawie karnym, „Przegląd Prawa Karnego” 1993, nr 8, s. 5-18.

Wróbel W., Struktura normatywna przepisu prawa karnego, „Ruch Prawniczy, Ekonomiczny i Socjologiczny” 2003, nr 3, s. 93-103. Wróbel W., Znamiona normy sankcjonowanej i sankcjonującej w przepisie prawa karnego, Kraków 1992, rozprawa doktorska niepubl.

Wróbel W., Zoll A., Polskie prawo karne. Część ogólna, Kraków 2010.

Zawłocki R. (w:) Kodeks karny. Część ogólna, red. M. Królikowski, R. Zawłocki, Warszawa 2017.

Zoll A., Kontratypy a okoliczności wyłączające bezprawność czynu (w:) Okoliczności wyłączające bezprawność czynu. Materiały IV Bielańskiego Kolokwium Karnistycznego, red. J. Majewski, Toruń 2008.

Zoll A., O normie prawnej z punktu widzenia prawa karnego, „Krakowskie Studia Prawnicze” 1991, nr 23, s. 69-95.

Żółtek S., Znaczenie normatywne ustawowych znamion typu czynu zabronionego. Z zagadnień semantycznej strony zakazu karnego, Warszawa 2016. 